\title{
Confinement and Tritium Stripping Systems for APT Tritium Processing
}

by

R. H. Hsu

Westinghouse Savannah River Company

Savannah River Site

Aiken, South Carolina 29808

L. K. Heung

DOE Contract No. DE-AC09-96SR18500

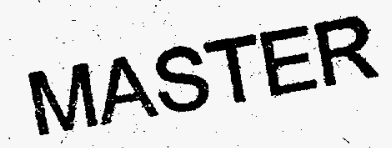

This paper was prepared in connection with work done under the above contract number with the U. S.

Department of Energy: By acceptance of this paper, the publisher and/or recipient acknowledges the U.S. Government's right to retain a nonexclusive, royalty-free license in and to any copyright covering this paper, along with the right to reproduce and to authorize others to reproduce all or part of the copyrighted paper. 


\title{
WSRC-RP-97-00887
}

Confinement and Stripping Systems for APT Tritium Processing (U)

\author{
Rev. 1 \\ October 20, 1997
}

Robert H. Hsu

L. Kit Heung

Savannah River Technology Center

Westinghouse Savannah River Company

Aiken, SC 


\section{DISCLAIMER}

This report was prepared as an account of work sponsored by an agency of the United States Government. Neither the United States Government nor any agency thereof, nor any of their employees, makes any warranty, express or implied, or assumes any legal liability or responsibility for the accuracy, completeness, or usefulness of any information, apparatus, product, or process disclosed, or represents that its use would not infringe privately owned rights. Reference herein to any specific commercial product, process, or service by trade name, trademark, manufacturer, or otherwise does not necessarily constitute or imply its endorsement, recommendation, or favoring by the United States Government or any agency thereof. The views and opinions of authors expressed herein do not necessarily state or reflect those of the United States Government or any agency thereof.

This report has been reproduced directly from the best available copy.

Available to DOE and DOE contractors from the Office of Scientific and Technical Information, P.O. Box 62, Oak Ridge, TN 37831; prices available from (615) 576-8401.

Available to the public from the National Technical Information Service, U.S. Department of Commerce; 5285 Port Royal Road, Springfield, VA 22161. 


\section{DISCLAIMER}

Portions of this document may be illegible electronic image products. Images are produced from the best available original document. 


\title{
WSRC-RP-97-00887
}

\section{Confinement and Stripping Systems for APT Tritium Processing (U)}

\author{
Rev. 1
}

October 20, 1997

Prepared By:

Antston

R. H. Hsu, CHTS, SRTC

S. k. Iteung

L. K. Heung, CHTS, SRTC

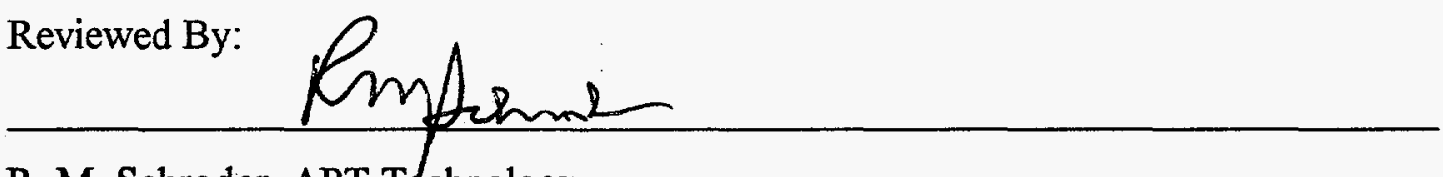

R. M. Schroder, APT Technology

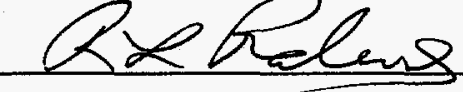

R. L. Rabun, Tritium Engineering

Approved By:

T. Motyka, CHTS, SRTC

Classification Reviewed By:

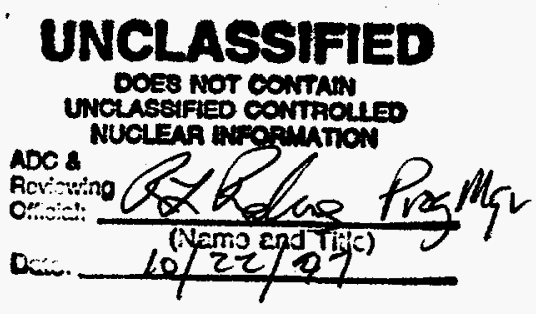





\section{List of Acronyms and Abbreviations}

\begin{tabular}{|c|c|}
\hline AECL & Atomic Energy of Canada, Limited \\
\hline $\mathrm{Ag}$ & Silver \\
\hline ALARA & As Low As Reasonably Achievable \\
\hline APT & Accelerator for the Production of Tritium \\
\hline Ar & Argon \\
\hline ASTM & American Society of Testing and Materials \\
\hline $\mathrm{Bq}$ & Becquerel $(=2.703 \mathrm{E}-11 \mathrm{Ci})$ \\
\hline $\mathrm{C}$ & Carbon \\
\hline $\mathrm{C}$ & Celsius degree (unit of temperature) \\
\hline CAM & Continuous Air Monitor \\
\hline $\mathrm{cc}$ & Cubic centimeter \\
\hline CEA & Commissariat a l'Energie Atomique \\
\hline $\mathrm{cfm}$ & cubic feet per minute \\
\hline CFFTP & Canadian Fusion Fuels Technology Project \\
\hline $\mathrm{Ci}$ & Curies \\
\hline CLWR & Commercial Light Water Reactor \\
\hline $\mathrm{Cu}$ & Copper \\
\hline $\mathrm{D}$ & Deuterium Isotope of Hydrogen \\
\hline $\mathrm{D} 2 \mathrm{O}$ & Deuterium oxide (heavy water) \\
\hline $\mathrm{D} \& \mathrm{D}$ & Decontamination \& Decommissioning \\
\hline DBA & Design Basis Accidents \\
\hline DCS & Distributed Control System \\
\hline DF & Decontamination Factor \\
\hline DOE & Department of Energy \\
\hline dpm & disintegrations per minute \\
\hline DTRF & Darlington Tritium Removal Facility (Canada) \\
\hline ERS & Effluent Recovery System (Mound) \\
\hline ETHEL & European Tritium Handling Experimental Lab \\
\hline${ }^{\circ} \mathrm{F}$ & Fahrenheit degree (unit of temperature) \\
\hline $\mathrm{ft}$ & foot or feet \\
\hline gpm & gallons per minute \\
\hline h & hour \\
\hline $\mathrm{H}$ & Hydrogen (Protium Isotope) \\
\hline $\mathrm{He}-3$ & Helium-3 \\
\hline HEPA & High Efficiency Particulate Air (Filter) \\
\hline HITEX & High Temperature Isotopic Exchange (Chalk River Lab, Canada) \\
\hline HTO & Hydrogen Tritium Oxygen (Tritiated water) \\
\hline HVAC & Heating, Ventilation and Air Conditioning \\
\hline IC & Ion Chamber \\
\hline I. D. & Inside diameter \\
\hline ITER & International Thermonuclear Experimental Reactor \\
\hline
\end{tabular}




\begin{tabular}{|c|c|}
\hline JAERI & Japan Atomic Energy Research Institute \\
\hline JCW & Job Control Waste \\
\hline JET & Joint European Torus \\
\hline JRC & Joint Research Center (Europe) \\
\hline${ }^{\circ} \mathrm{K}$ & Degree Kelvin \\
\hline $\mathrm{kg}$ & kilogram (1000 gram) \\
\hline 1 & liter \\
\hline $\begin{array}{l}\text { LANL } \\
\mathrm{m}^{3}\end{array}$ & $\begin{array}{l}\text { Los Alamos National Laboratory } \\
\text { cubic meters }\end{array}$ \\
\hline MB & Metal-bellows (type of pump) \\
\hline $\mathrm{Mg}$ & Magnesium \\
\hline $\min$ & minute \\
\hline$\mu \mathrm{Ci} / \mathrm{cc}$ & micro $\left(10^{-6}\right)$ Curies per cubic centimeter \\
\hline mrem & millirem (absorbed radiation dose) \\
\hline MTF & Materials Test Facility \\
\hline NESHAP & National Emission Standards for Hazardous Air Pollutants \\
\hline NET & Next European Torus \\
\hline NNR & Non-Nuclear Reconfiguration (Project) \\
\hline OHN & Ontario Hydro Nuclear \\
\hline $\mathrm{Pa}$ & Pascal; SI unit of pressure $\left(1 \mathrm{~Pa}=1 \mathrm{~kg} / \mathrm{m}-\mathrm{s}^{2}=9.87 \mathrm{E}-6 \mathrm{~atm}\right)$ \\
\hline PCCS & Process Confinement and Clean-up System \\
\hline Pd & Palladium : : \\
\hline PMR & Palladium Membrane Reactor \\
\hline $\begin{array}{l}\text { ppm } \\
\text { psig }\end{array}$ & $\begin{array}{l}\text { Parts per million }\left(1 \mathrm{ppm}=12.5 \mu \mathrm{Ci} / \mathrm{cc}=12.5 \mathrm{Ci} / \mathrm{m}^{3}\right) \\
\text { pounds per square inch gauge }\end{array}$ \\
\hline $\mathrm{Pt}$ & Platinum \\
\hline $\mathrm{pCi} / \mathrm{ml}$ & pico $\left(10^{-12}\right)$ Curies per milliliter \\
\hline PPPL & Princeton Plasma Physics Lab \\
\hline P-V-T-C & $\begin{array}{l}\text { Pressure-Volume-Temperature-Composition (Tritium accountability } \\
\text { method) }\end{array}$ \\
\hline QA & Quality Assurance \\
\hline RMA & Radiological Material Area \\
\hline RSI & Resource Services Incorporated (diffuser manufacturer) \\
\hline RTF & Replacement Tritium Facility, SRS Building 233-H \\
\hline SAR & Safety Analysis Report \\
\hline SDD & System Design Description \\
\hline SI & System Internationalle (metric system) \\
\hline SNL-CA & Sandia National Laboratories - California \\
\hline SRS & Savannah River Site \\
\hline SRTC & Savannah River Technology Center \\
\hline $\mathrm{T}$ & Tritium Isotope of Hydrogen \\
\hline TCAP & Thermal Cycling Absorption Process \\
\hline TEF & Tritium Extraction Facility \\
\hline TERF & Tritium Effluent Recovery Facility (Mound) \\
\hline
\end{tabular}

Japan Atomic Energy Research Institute

Job Control Waste

Joint European Torus

Joint Research Center (Europe)

Degree Kelvin

kilogram (1000 gram)

cubic meters

Metal-bellows (type of pump)

Magnesium

minute

millirem (absorbed radiation dose)

Materials Test Facility

National Emission Standards for Hazardous Air Pollutants

Next European Torus

Non-Nuclear Reconfiguration (Project)

Ontario Hydro Nuclear

Process Confinement and Clean-up System

Palladium

Palladium Membrane Reactor

pounds per square inch gauge

Platinum

pico $\left(10^{-12}\right)$ Curies per milliliter

Princeton Plasma Physics Lab

Pressure-Volume-Temperature-Composition (Tritium accountability method)

Quality Assurance

Replacement Tritium Facility, SRS Building 233-H

Safety Analysis Report

System Design Description

System Internationalle (metric system)

Sandia National Laboratories - California

Savannah River Site

Savannah River Technology Center

Tritium Isotope of Hydrogen

Thermal Cycling Absorption Process

Tritium Effluent Recovery Facility (Mound) 
TFM \& C

TFTR

TPL

TPSS

TRL

TSDCS

TSF

TSFF

TSTA

$\mathrm{U}$

vol

WETF

WSRC

Z-Bed
Tritium Facility Modernization and Consolidation

Tokamak Fusion Test Reactor (Princeton)

Tritium Process Laboratory (Japan)

Tritium Process Stripping System

Tritium Research Lab (SNL-CA)

Tritium Storage and Delivery Clean-up System (Princeton)

Tritium Separation Facility

Tritium Systems Fabrication Facility (at Los Alamos)

Tritium Systems Testing Assembly (at Los Alamos)

Uranium

Volume

Weapons Engineering Tritium Facility (at Los Alamos)

Westinghouse Savannah River Company

Zeolite Bed 


\section{Table of Contents}

List of Acronyms and Abbreviations - iv

Executive Summary 1

1. Introduction 3

1.1 Typical Tritium Confinement System 4

1.2 Tritium Confinement/Stripping/Recovery Issues 5

1.2.1 Tritium Offgassing/Leaks $\quad 5$

1.2.2 Tritium Contamination 6

1.2.3 Tritium Oxide Formation 6

$\begin{array}{ll}\text { 1.2.4 Moisture/Oxygen Control } & 7\end{array}$

1.2.5 Hood vs. Glovebox Confinement 7

1.2.6 Recirculating vs. "Stagnant" Glovebox Operation 8

1.2.7 Positive vs. Negative Glovebox Operating Pressure 9

1.2.8 "Economical" Tritium Concentration for Recovery 9

1.2.9 Tritium Recovery from Tritiated Water 9

1.2.10 Ammonia Formation 10

$\begin{array}{ll}\text { 1.2.11 Pressurization of Zeolite Beds } & 10\end{array}$

2. Process Confinement and Clean-up System Functions and Requirements 11

$\begin{array}{ll}2.1 \text { Codes and Standards } & 11\end{array}$

2.2 PCCS Global Requirements 14

$\begin{array}{ll}2.3 \text { PCCS System Interfaces } & 15\end{array}$

2.4 Tritium Equipment Confinement Functions and Requirements 16

2.4.1 Equipment Confinement During Normal Operations 17

2.4.2 Equipment Confinement During Design Basis Events 17

2.4.3 Flammability of Confinement Atmosphere 17

$\begin{array}{ll}\text { 2.4.4 Pressure and Vacuum Protection } & 18\end{array}$ 
2.4.5 Confinement System Gas Temperature Control

2.4.6 Confinement System Access/Waste Removal

2.4.7 Structural Support for Equipment

2.4.8 Leak Rates

2.4.9 Monitoring Instrumentation

2.4.10 Materials of Construction

2.4.11 Human Factors

2.5 Tritium Stripping Functions and Requirements

2.5.1 Tritium Stripping

2.5.2 Stackable Tritium Gas Concentration

2.5.3 Stripper Capacity

2.5.4 Mode of Operation

2.5.5 Monitoring Instrumentation

2.6 Tritium Recovery from Stripper Systems

3. Survey of Tritium Confinement Systems

3.1 Large-Scale Tritium Confinement Systems in Use 26

\begin{tabular}{l|r}
3.2 Tritium Confinement Technologies & 28
\end{tabular}

3.3 Tritium Stripping Technologies $\quad 29$

3.3.1 Oxidation-Absorption Technology $\quad 29$

3.3.2 Getter Technology 31

3.3.3 Diffuser Technology : 33

3.3.4 Impact of PCCS Feed Contaminants on Stripper Technology 34

3.4 Tritium Recovery Technologies

4. Recommendations for APT-TSF PCCS Design

5. Technical Uncertainties, Data Needs and R\&D Opportunities

6. References 
Appendix A, Tritium Confinement Systems in Use

A1. SRS 233-H (RTF)

A-2

A2. SRS 232-H Function Test Facility

A-4

A3. LANL TSTA

A-6

A4. LANL TSFF

A-8

A5. LANL WETF

A-10

A6. SNL Tritium Research Lab

A-12

A7. Mound T-Building/SW Building

A-14

A8. Princeton TFTR Tritium Facility

A-16

A9. Chalk River CRITIC System

A-20

A10. Chalk River High-Level Tritium/HITEX Gloveboxes

A-22

A11. Ontario Hydro Technologies

A-24

A12. AWE

A-26

Appendix B Vendor Information

B-1 
Table 1 PCCS Instrumentation Requirements

20

Table 2

Proposed PCCS Design for APT-T'SF

39

Table A1

Tritium Confinement Systems in Use

A-1

Table B1

Confinement and Clean-up Systems Vendors

B-2

Table B2

Confinement System Accessories Vendors

B-4

\section{List of Figures}

Figure 1

Typical Tritium Confinement System

4

Figure 2

PCCS Oxidation-Absorption Process Schematic

31

Figure 3

PCCS Getter Process Schematic

32 


\section{Executive Summary}

This report identifies functions and requirements for the tritium process confinement and clean-up system (PCCS) and provides supporting technical information for the selection and design of tritium confinement, clean-up (stripping) and recovery technologies for new tritium processing facilities in the Accelerator for the Production of Tritium (APT). The results of a survey of tritium confinement and clean-up systems for large-scale tritium handling facilities and recommendations for the APT are also presented.

The authors recommend that APT tritium processing equipment be confined in gloveboxes, or secondary jackets, in keeping with current SRS practice and As Low As Reasonably Achievable principles. It is important to minimize tritium leaks and air/moisture ingress into confinement systems and to avoid the use of hydrogen-exchangeable materials inside the confinement atmosphere. Purging of tritium-contaminated gas from confinement atmosphere should be minimized to reduce environmental tritium releases. It is proposed to investigate possibly operating the gloveboxes under both slightly positive or negative pressure relative to the room to reduce the impact of diurnal barometric pressure changes on purge gas flow, and to minimize leak rate. A physically large PCCS stripper system may be located outside of glovebox confinement, if justified by tritium inventory, dose and risk considerations.

Based on the conceptual APT process with several water loops, large-scale equipment and susceptibility of confinement system to air/moisture intrusion, and anticipated siting of the APT at the SRS, the recommended stripper technology is the oxidation-absorption process. The advantages of the oxidation-absorption process over getter technology include proven performance, high efficiency, and robustness to handle air/moisture conditions. Getter technology is attractive in that it does not purposely generate tritiated water, but does require a pre-treatment sacrificial getter to remove both oxygen and water. A getter process will thus generate more sacrificial (and expensive) waste getter beds than the conventional SRS zeolite bed recovery process using $\mathrm{Mg}$ or $\mathrm{U}$ beds. Acceptable performance of tritium getters following multiple regenerations also remains to be demonstrated. 
No recommendation is made on the preferred tritium recovery technology from tritiated water. It is recommended that $\mathrm{R} \& \mathrm{D}$ continue on technologies that may replace the conventional $\mathrm{Mg}$ or $\mathrm{U}$ water cracking process: solid oxide electrolysis and regenerable iron bed technologies at SRS and the palladium membrane reactor (PMR) technology at LANL. 


\section{INTRODUCTION}

Tritium confinement is an important issue in the design of new tritium facilities and in the operation of existing ones. All modern tritium handling processes require a secondary tritium confinement system to minimize potential for worker uptake, environmental impact and dose to the public. Secondary confinement systems are generally designed to either 1) dilute and disperse, or, 2) confine and recover tritium. For systems handling very small quantities of tritium with very small environmental impact and dose consequences, it may be acceptable to dilute and disperse. For most facilities in the DOE, the general accepted goals are to minimize tritium release to the environment, worker exposure, potential for tritium uptake and generation of tritiated waste. The function of a tritium process confinement and clean-up system (PCCS) is to confine, capture and recover any tritium that might escape the primary process. The challenge is to do so simply, cost effectively and to minimize generation of radioactive waste.

Over the past decade, tritium institutions, both domestic and foreign, have spent significant efforts trying to develop an ideal tritium confinement system. Some of these developments and results have been published in the open literature. However, many of the data and experiences were scattered and needed to be summarized and analyzed to help design the next generation of large-scale tritium handling facilities.

This report represents a summary and analysis of existing data on tritium confinement, clean-up and recovery technologies. The results will provide up-to-date information for the design of new confinement and clean-up systems for the Accelerator for the Production of Tritium - Tritium Separation Facility (APT-TSF) and for the improvement of existing ones. The results of this study will:

- Identify Tritium PCCS Functions and Process and Technical Requirements for the APT.

- Summarize the design and performance data for large-scale tritium process confinement and clan-up systems in use.

- Provide supporting technical information for the selection and design of the best tritium confinement and clean-up technologies for new tritium facilities in the APT-TSF. 
- Identify areas of data needs and technical uncertainties and describe ongoing/planned R \& D efforts to address these needs.

\subsection{Typical Tritium Confinement System}

A typical tritium confinement system consists of a secondary confinement barrier, a tritium cleanup process (commonly referred to as a tritium stripper system at SRS) and a tritium recovery process (See Figure 1). Tritium in primary confinement systems such as process equipment, tank, or pipe may escape confinement. The secondary confinement barrier captures and prevents the tritium from being released to the environment. The tritium stripper system removes tritium from the confined atmosphere or blanket gas. A tritium recovery process then recovers tritium from the tritium stripper system so that it can be separated, purified and reused. Tritium processing equipment that is placed in a leak-tight vacuum jacket would be secondarily confined. If the jacketed equipment is placed inside a glovebox, tertiary confinement would be achieved. Another method of achieving tertiary confinement is to design the tritium process room with a capability for isolating its room ventilation system and to equip it with a room air clean-up system.

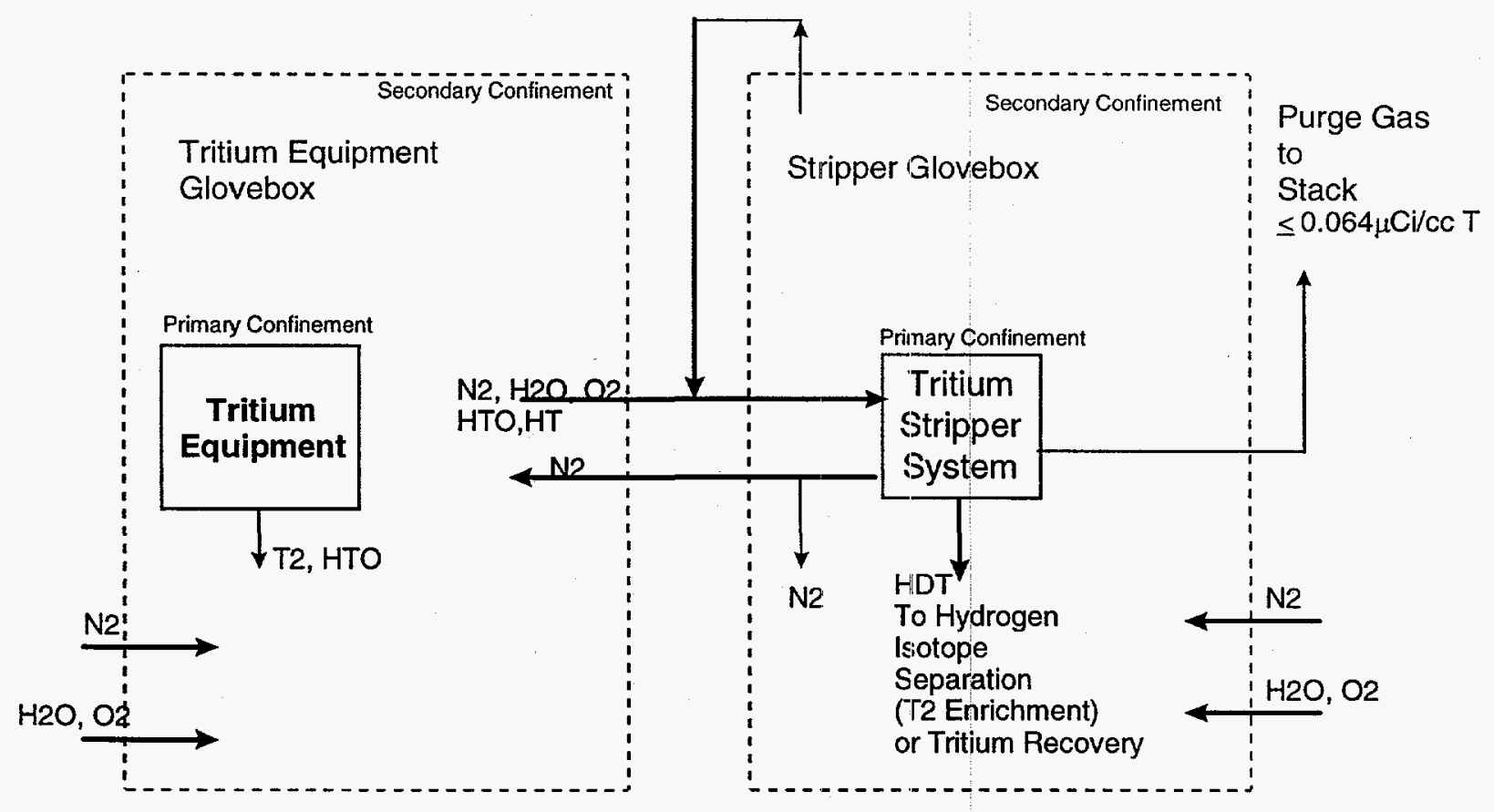

Figure 1. Typical Tritium Confinement System 


\subsection{Tritium Confinement/Stripping/Recovery Issues}

The primary function of the confinement barrier is to keep tritium in the confinement atmosphere. The confinement barrier must also minimize intrusion into the confined atmosphere by active elements, mainly oxygen and water, which are present in the ambient atmosphere. Oxygen and water can come through the confinement barrier via leaks and permeation (e.g. through gloves). The mass flow rates of oxygen and water coming though the confinement barrier can easily exceed the leak rate of tritium from process equipment and will determine the complexity and capacity requirements of the tritium stripping and recovery processes. A successful confinement system must address these and other issues such as tritium off-gassing and tritium oxide (tritiated water) formation. Confinement design, selection of the barrier material and the operating strategy involving the confined atmosphere are all important factors in improving the effectiveness of the confinement barrier. Other issues involve the selection of the appropriate tritium stripping technology, and recovery of tritium from the confinement atmosphere stripper system.

\subsubsection{Tritium Offgassing/Leaks}

Tritium offgassing from contaminated process equipment and process leaks into the confinement system represent the tritium source term that must be controlled. Tritium offgassing/leak rates determine the demand on the stripping system and the achievable background level of tritium in the confinement atmosphere. A large tritium source term will produce a higher tritium background and lead to the need for a large stripper system. Therefore, tritium offgassing and leaks should be minimized as much as possible, particularly leaks.

Tritium offgassing is hard to control and predict. Since tritium absorbs into almost all materials, there is reverse offgassing when the tritium source is removed. The rate of offgassing depends on the "reservoir" of tritium permeated into a material, ambient pressure, temperature of material, and humidity of the surrounding gas. Surface detection of tritium offgas is not sufficient to estimate total tritium that has permeated into a material matrix. Knowledge of the equipment processing and exposure history to tritium is necessary to calculate the overall tritium permeation into a material matrix. 


\subsubsection{Tritium Contamination}

Tritium contamination, particularly in the oxide and organic forms, tends to be "sticky." It will stick to surface oxides and diffuse into and out of metal matrices. Tritium offgassing may originate with any tritium-contaminated equipment inside the confinement, particularly those exposed for extended periods of time to high concentrations of tritium at elevated temperatures and pressures and with materials that contain hydrogen-exchangeable components (e.g., hydrocarbon-based polymers).

There are, generally speaking, two types of tritium contamination: fixed contamination and removable contamination. Fixed tritium contamination, that is, contamination not effectively removable by wiping, may be in the form of a metal tritide. This means that tritium has actually diffused or permeated into the metal components (metal films, pump housings, etc.). Metal tritide is a very stable form and can only be effectively removed by heating (for example, to about $350^{\circ}$ $\mathrm{C}$ for titanium tritide). Removable or smearable tritium contamination is generally in the form of tritium oxide or tritiated organic (oil, grease, etc.). Tritium oxide formation in tritium-processing equipment is hard to avoid and will form any time tritium is exposed to oxygen, air or moisture. It is formed by oxidation with oxygen or isotopic exchange with elemental hydrogen in moisture, oils and hydrocarbon polymers.

Certain tritium contamination will exhibit behavior features of both "fixed" and "removable" contamination. Elemental tritium will diffuse into any metal and will diffuse back out when the source is removed. This is particularly true for high-concentration tritium gas contained under pressure. Tritium that diffuses out of tritium-contaminated metal will generate removable HTO contamination at metal surfaces, if exposed to moisture or oxygen. This contamination may be removed for a short period of time, but "re-appear" at a later time.

\subsubsection{Tritium Oxide Formation}

Tritium reacts with oxygen to form tritium oxide. The rate of reaction increase with temperature, the presence of catalytic surfaces and the intentional use of catalysts. Uncontrolled tritium oxide formation is undesirable because it is much more toxic, by a factor of about 25,000 times, than elemental tritium. Tritium oxide is formed purposely in a heated catalytic reactor 
using conventional oxidation-absorption technology. Tritium oxide is also formed from isotopic exchange of tritium with water.

Tritium oxide formation contributes to contamination of the inner surfaces of confinement systems such as gloveboxes. The tritium oxide level inside a confinement system must be minimized for hands-on work by operating personnel. If not properly controlled, contamination level on glovebox inner surfaces may get a level as to require decontamination before open-panel maintenance can be conducted.

\subsubsection{Moisture/Oxygen Control}

Moisture and oxygen are two active elements in confinement atmosphere gas that are difficult to avoid. Moisture and oxygen in the confinement system atmosphere typically originate from air inleaks and glove permeation. Permeated or inleaked moisture then isotopically exchanges with tritium to form tritium oxide. Oxygen oxidizes metallic surfaces, leading to trap sites for tritium, and reacts with tritium to form tritiated water. Controlling oxygen in the glovebox atmosphere leads to the need for an oxygen getter, generating a solid waste stream, or purging of glovebox atmosphere gas to stack and associated tritium release. Controlling moisture leads to the use of a desiccant such as zeolite. This moisture must be processed to recover tritium or disposed of as solid waste. Thus, both moisture and oxygen ingress should be minimized to reduce tritium oxide formation and contamination.

Moisture and oxygen ingress may be minimized by minimizing the number of leaks in the confinement system at start-up, covering gloveports when not in use (either on the outside or inside of the gloveboxes), minimizing the number of glovebox penetrations and gloveports, and operating a glovebox confinement system at positive pressure relative to process room. A less desirable method is to allow higher background levels of oxygen and moisture in the confinement atmosphere gas to reduce the concentration driving force for permeation.

\subsubsection{Hood vs. Glovebox Confinement}

Equipment located in air hoods are generally easier to access and maintain. However, there is more waste generated in the form of personal protective equipment (PPE) such as kraft paper, plastic sheets, plastic suits and shoe covers when maintenance is required. 
Compared to the use of high-flow air hoods, which are generally designed to dilute and discharge tritium and to protect the worker, the use of glovebox confinement systems lead to the following benefits:

- Trapping of tritium in case of a release

- Reduced job control waste

- Simplified operations due to streamlined line-break procedures

The cost to achieve these benefits include:

- Increased equipment and instrumentation capital cost

- Need for tritium stripper and/or recovery systems

- Higher tritium contamination on equipment and glovebox surfaces.

\subsubsection{Continuous Circulation vs. "Stagnant" Glovebox Operation}

In the Building 233-H RTF, glovebox atmosphere gas is continuously processed through a stripper system for the removal of tritium and moisture. An alternative mode of operation is to keep the glovebox gas stagnant or isolated and only pump it to a stripper system for cleaning when trigger concentration levels of tritium, moisture or oxygen are reached. The stripped gas may be returned to the glovebox or discharged to stack, with fresh gas used as make-up to the glovebox. A number of criteria may be used to compare and select the appropriate mode of operation:

- Complexity of equipment

- Tritium removal efficiency

- Water loading

- Ease of operation

- Waste generation

- Cost (equipment/operational)

Continuous circulating system may achieve and maintain lower background tritium level inside a glovebox. It also promotes steady-state operation of the stripper system, allowing its performance to be monitored continuously. A lower level of moisture in glovebox atmosphere gas is also achieved. Isolated, on-demand systems tend to be operated batch-wise. Advantages include reduced water permeation and water loading on z-beds. 


\subsubsection{Positive vs. Negative Glovebox Operating Pressure}

DOE Order 6430.1A recommends operating tritium gloveboxes or confinement systems under negative pressure to the process room. Negative glovebox pressure minimizes tritium release to room and is more tolerant of pinhole leaks in gloves. However, operating experience at LANL, SRS and Chalk River Lab have shown that if it is critical to maintain very low levels of oxygen and moisture, gloveboxes should operate at positive pressure, particularly for large gloveboxes. Under positive pressure mode of operation, leaks would go from the glovebox to the room, minimizing oxygen and moisture intrusion into the glovebox. The advantages include prolonged life of getter beds, if used as tritium stripping system, reduced moisture duty/loading on z-beds if conventional oxidation-absorption technology is used, and easy detection of leaks.

\subsubsection{Economical Tritium Concentration for Recovery}

Recovery of tritium from tritiated water requires capital investment in equipment, cost of operating labor and potential low-level waste generation (e.g. magnesium or uranium waste beds if using current SRS technology). The benefits of tritium recovery include the value of tritium, reduced cost of low-level waste disposal and reduced effluent tritium gas release to the environment. There is thus a level of tritium content that determines the desirability of conducting tritium recovery. At the Princeton TFTR, zeolite beds containing more than $1000 \mathrm{Ci}$ are shipped to the SRS for tritium recovery. Zeolite beds containing less than $1000 \mathrm{Ci}$ are shipped to LANL for burial.

\subsubsection{Tritium Recovery from Tritiated Water}

Conventional stripping technology converts elemental tritium to tritium oxide and captures the oxide on zeolite moisture absorber beds. Trapped tritiated water in zeolite beds may be processed to recover tritium. Current SRS technology uses a $\mathrm{Mg}$ or $\mathrm{U}$ bed to crack water. Water reacts with heated $\mathrm{Mg}$ or $\mathrm{U}$ to form an oxide and release hydrogen gas. The used or spent $\mathrm{Mg}$ or $\mathrm{U}$ bed becomes waste. RTF stripper system experience shows $>99.9 \%$ of moisture on zeolite beds is non-tritiated water. About half of the water appears to come from moisture leaking into gloveboxes due to negative pressure operation and half due to glove permeation. $\mathrm{RTF}$ recovery regeneration operations are labor intensive and somewhat more time consuming 
than originally anticipated. It would be highly desirable to reduce the amount of water that must be processed, as well as regeneration frequency, cycle time and waste $\mathrm{Mg}$ or $\mathrm{U}$ beds produced.

\subsubsection{Ammonia Formation}

In confinement systems using nitrogen as equipment blanketing gas, nitrogen in the glovebox atmosphere may react with tritium to form tritiated ammonia (represented by NQ3). However, ammonia formation is most likely to happen inside tritium process lines, where inleaked nitrogen may come into contact with high concentrations of tritium and other hydrogen isotopes. Tritium leaking into a nitrogen atmosphere glovebox should preferentially react with oxygen in the blanket gas to form oxide.

\subsubsection{Pressurization of Zeolite Beds}

Zeolite beds are used in process lines to remove moisture and in conventional oxidationabsorption stripper systems. Disposal of zeolite beds containing tritiated water should make sure they are vented. Radiolysis of water from tritium beta decay energy and helium formed by tritium decay will cause pressurization of the zeolite bed if it is not vented. This pressure builds up with time as a function of water loading and tritium content. The rate of pressurization needs to be quantified for disposal zeolite beds, for designing $\mathrm{z}$-bed recovery processes, and to determine system pressure rating requirements and operating strategy. 


\section{PROCESS CONFINEMENT AND CLEAN-UP SYSTEM FUNCTIONS AND REQUIREMENTS}

This section contains the specific functions, system requirements and design criteria which guide the design of a tritium Process Confinement and Clean-up System (PCCS). The functional performance requirements, defined in the APT Facility Design Description (Tuggle and Lohmeier, 1997) applicable to this system have been developed in greater detail.

Design and performance criteria resulting from established SRS, National codes and standards, and DOE Orders for tritium process equipment are described in Section 2.1 Global system requirements applicable to tritium confinement, stripping and tritium recovery design are listed in Section 2.2. PCCS system interfaces with the rest of the APT are covered in Section 2.3. The remaining sections discuss specific functions and performance/design requirements for tritium equipment confinement (Section 2.4), confinement atmosphere stripping (Section 2.5) and tritium recovery from stripper systems (Section 2.6).

Tritium equipment confinement, tritium stripping of confinement atmosphere and tritium recovery technologies capable of meeting the functions and requirements identified in this Section are discussed in Section 3.

\subsection{Codes and Standards}

A number of codes and standards govern the design of tritium processing equipment at SRS. A number of applicable codes and standards to SRS confinement system design have been abstracted from the following references:

- DOE Order 6430.1A, Sections 1326-5,-6,-7

- DOE/TIC-11603 Nonreactor Nuclear Facilities: Standards and Criteria Guide, Rev 1, Chapter 4 and Appendix $\mathbf{J}$

- Engineering Design Guide 13090-01-G, SRS Hood and Glovebox Standards, 6/93 
Several other references also provide useful information:

- AGS-G0001-1994, "Guidelines for Gloveboxes by American Glovebox Society"

- WSRC-IM-92-43, SRS Process Ventilation Design Guide

- WSRC-03-90-145, SRS Glovebox Manual and Guide, (replaces EWR 862257, "SRS Glovebox Design, Procurement and Installation Guide, 4/87)

- SRS Specification 7187. Hood and Glovebox Standards, Rev. 2, 8/86

- "Project S-4828 Tritium Consolidation: Task 22: Develop Glovebox Criteria/References," 120:EPD-SE-2106, Memorandum, K. F. McLaurin to H. T. Harris, et al., June 3, 1993

\section{DOE Order 6430.1A}

1. Tritium stored in $\mathrm{U}$ bed should not reach eutectic temperature of Fe and $\mathrm{U}\left(725^{\circ} \mathrm{C}\right)$.

2. Process systems should minimize T2 leakage.

3. Glovebox should use nitrogen or argon for equipment blanket gas, not air.

4. Glovebox atmosphere should be maintained at a lower pressure than surrounding.

5. Diffusion resistant material should be used to limit tritium leakage.

6. Design should provide for isolating areas containing tritium process from office.

7. Design should provide for isolating tritium source.

8. Tritium monitors should be installed to detect conditions requiring corrective action.

9. Primary confinement barrier must not use materials subject to hydrogen-embrittlement.

10. Use nonflammable hydraulic, lubricating and cooling liquids.

11. Consider an emergency tritium gas clean up system when handling large quantities of $\mathbb{T} 2$.

12. Consider surveillance systems to monitor process piping, tanks, liquid effluents and lowelevation components.

13. Tritium gas in tanks/piping should be in hoods/gloveboxes/buildings.

14. Pressure and missile scenarios may argue against glovebox use.

15. Ensure the integrity of glovebox for normal operations/design basis accidents (DBAs).

16. Use rupture disk, pressure relief valves, sealpots, or bubblers for pressure protection. 
17. Install features for safe introduction/removal of materials from process confinement.

18. Use traps or effluent recovery units to reduce tritium release.

19. Minimize penetrations to glovebox.

20. Penetrations shall prevent tritium migration.

21. Penetrations shall ensure proper differential pressure and confinement vent flow.

22. Install effluent removal system to handle tritium leakage into glovebox; unless justified by safety analysis report (SAR).

23. Glovebox shall be supplied with sufficient vent air in case of glovebox breach.

24. All exhaust stacks that may contain T2 should be monitored.

25. Consider radiolysis in sealed waste containers (z-beds, etc.).

26. Consider tritiated solid waste ( $\mathrm{z}$ beds, absorbers beds, ...) in design.

27. Consider tritiated liquid waste (oil, water, ...) in design.

28. Consider airborne radioactive effluents in design.

29. All exhaust outlets that may contain T2 shall have two monitoring systems.

30. Consider providing a dedicated area for tool decon (heat, solvent wipe).

31. Tritium requires safe guarding at category III level. (ck to see if still true?)

32. . Consider rad sources, activation products, high voltage, cryogenic fluids, laser in design.

33. Nuclear criticality safety is not applicable..

\section{DOE/TIC 11603}

34. If a confinement barrier is not a pressure vessel, the capability to maintain normal air flow paths to control the release of radioactive material from its enclosed volume should be assumed to be negated whenever pressure inside the volume exceeds a minimum negative pressure.

35. Periods when a confinement cannot maintain a minimum negative pressure should be treated as abnormal outleakage from confinement volume, with reduced credit for clean-up system in the normal exhaust path. Credit may be taken for clean-up system specifically designed to protect against an uncontrolled release of radioactivity during and after a confinement pressure excursion. 
36. Confinement ventilation should maintain desired flow characteristics.

37. Confinement ventilation system should have suitable redundancy.

38. Ventilation system should have Class $1 \mathrm{E}$ electric power, if needed to maintain controlled continuous confinement air flow. Consider need to cperate on back-up power.

39. Provide for confinement air cleanup system to limit tritium release and contamination.

40. Air filtration units should be functional and retain collected radioactive materials.

41. The number of air filtration units should be based on the type and quantity of radioactive material to be confined.

42. Air filtration units should be close to radioactive material sources.

43. Air filtration units should be properly shielded.

\section{SRS Standard 13090}

44. Components should be standardized.

45. Interior Finish should be smooth (2B finish).

46. All internal radii should be $3 / 8$ " minimum.

47. Confinement butt welds should be at center of glovebox.

48. Weld stud and fasteners should be minimum $3 / 8$ " diameter.

49. Liquid handling gloveboxes should have sumps.

50. Gas tight gloveboxes must have over/under pressure protection.

51. Water jacketed glovebox must have steam relief vents.

52. Fire suppression system is required if glovebox atmosphere contains $>1 \%$ oxygen.

53. Negative differential pressure of $0.3^{\prime \prime}$ water column inside enclosure.

54. Minimum maintenance Air Hood Velocity is $125 \pm 25$ linear feet $/ \mathrm{min}$.

\subsection{PCCS Global Requirements}

The operability of the tritium PCCS is needed to support tritium processing operations in the APT-TSF. Therefore, redundant, independent components shall be utilized for essential operation and maintenance of the PCCS. The PCCS must be designed to meet the following criteria: 
- Confine or minimize the effects of an uncontrolled release of radioactive material such that onsite and off-site doses and effluent concentrations are maintained within recommended guidelines during normal facility operating conditions.

- Minimize the release of radiological hazards in gaseous effluents.

- Minimize chemical releases to the environment.

- Ensure containment of tritium.

- Minimize accidental release of tritium from process equipment scenario from leading to rupture of secondary confinement.

- Arrangement of PCCS equipment must be accessible and facilitate operation and maintenance.

- Minimize radioactive material exposure/dose to operating personnel.

- Minimize waste generation. Hazardous materials should not be used as a result of this project for degreasing or decontamination. Mercury is not allowed to come in contact with process systems in the TSF.

- PCCS process and support equipment fluids and additives shall minimize or preclude use of hazardous materials, equipment fluids and additives. Facility operations will minimize releases of radiological and chemical hazards to the environment, minimize personnel exposure and apply ALARA concepts.

- PCCS equipment layout should be designed to facilitate end-of-life D \& D.

\subsection{PCCS System Interfaces}

The PCCS must tie in to other process, control and support systems in the APT and TSF. These system interfaces include the following:

- Target/Blanket Building

- Tritium Extraction Facility

- Heat Removal System

- Remote Handling

- Rad Waste System

- Process Nitrogen Purge/Evacuation 
- Hydrogen Isotope Separation

- Hydrogen/Tritium Storage Beds and Tanks

- Balance of Plant

- Analytical Lab/Mass Spec system

- He-3 Supply

- Integrated Control/Distributed Control System (DCS)

- Service/inert gases

- Process chilled water

- Power/Electrical services

\subsection{Tritium Equipment Confinement Functions and Requirements}

Primary confinement systems consist of equipment such as process piping, valves, tanks, pumps and instrument probe casings that come into direct contact with tritium and must meet current SRS Tritium Facilities specs. Secondary confinement systems are mechanical systems that surround and contain tritium leaks and releases from the primary confinement systems. There are several types of secondary confinement systems, including: glovebox, vacuum jackets, glove bag, airlock, portable airbag, etc.

It is assumed that APT-TSF equipment will be secondarily confined in gloveboxes due to potentially significant quantities of tritium that may be present. PCCS stripper and tritium recovery systems may be confined in air hoods, if justified by dose and risk considerations. To protect equipment subject to prolonged exposure to high-temperature and high-tritium concentration, such as diffuser systems, from potential tritium permeation and offgassing, secondary confinement such as a vacuum jacket is recommended.

The following confinement system functions and requirements:

- Equipment confinement during normal operations

- Equipment confinement during design basis events

- Flammability of Confinement Atmosphere

- Pressure and Vacuum Protection

- Confinement system gas temperature control 
- Confinement system access/waste removal

- Structural support for equipment

- Leak rates

- Monitoring Instrumentation

- Materials of Construction

\subsubsection{Equipment Confinement During Normal Operations}

\section{Functions}

- The PCCS shall minimize the release of tritium in gaseous effluents from the tritium processing systems: inert separation, isotope separation, process pumps, tanks, valves, tritium clean-up systems, tritium recovery systems.

- The PCCS shall minimize the release of radiological hazards (other than tritium) in gaseous effluents from the tritium processing systems.

\section{Requirements}

- The PCCS shall operate to maintain personnel exposure to $\leq 70 \mathrm{mrem} / \mathrm{yr}$.

\subsubsection{Equipment Confinement During Design Basis Events}

\section{Function}

- The PCCS shall confine or minimize the effects of an uncontrolled release of tritium and other radioactive materials from primary confinement during design basis events (DBEs) such that onsite and off-site doses and effluent concentrations are maintained within recommended guidelines.

\section{Requirement}

- The PCCS shall limit the tritium source inside each glovebox module to $<210 \mathrm{~g}$, , or as determined by a facility safety analysis.

\subsubsection{Flammability of Confinement Atmosphere}

\section{Function}

- The PCCS shall provide for "inert" confinement atmosphere to prevent formation of flammable gas mixtures and preclude the need for a fire suppressant system. 


\section{Requirement}

- The PCCS confinement atmosphere may be nitrogen or argon, as appropriate.

\subsubsection{Pressure and Vacuum Protection}

\section{Functions}

- The PCCS confinement systems shall be designed for over-pressure and vacuum protection during all phases of operation.

\section{Requirements}

- The PCCS gloveboxes shall be designed such that integrity is maintained by pressure balancing and by pressure relief through sealpots or bubblers (set at \pm 3 in. water) during an overpressure or vacuum condition.

- The glovebox pressure control module should be designed to detect and signal a change of + \pm 0.1 torr.

- The design should take into consideration failure of a primary confinement system.

\subsubsection{Confinement System Gas Temperature Control}

\section{Function}

- The PCCS confinement systems shall be designed to control the temperature of the gas in the confinement atmosphere.

\section{Requirements}

- Heat removal capability shall be installed to maintain glovebox atmosphere gas temperature within $20^{\circ} \mathrm{C}$ of ambient process room temperature.

- Glovebox may require cooling if large motors, pumps, heaters and/or heated equipment (e.g. diffusers) are confined.

\subsubsection{Confinement System Access/Waste Removal}

\section{Requirements}

- The PCCS must provide a sufficient number of glove ports for accessing tritium process equipment inside the glovebox.

- The PCCS shall provide for penetration ports for electrical cables, process lines and support systems such as nitrogen and cooling water lines. 
- The number of PCCS shell penetrations shall be minimized to the extent practical.

- The PCCS shall provide methods/equipment to treat, accumulate, transport, segregate, minimize, handle and process and package waste (e.g. hoists).

- The PCCS shall provide antechambers and/or airlocks on each module to allow equipment to be transferred into or out of the confinement system, minimizing release of tritium to room atmosphere or introduction of oxygen into the confinement system.

- Antechambers/air locks must be equipped with vacuum systems for pump down and flush gas systems.

- There is no criteria for antechamber transfer with respect to oxygen or tritium levels; the antechambers are evacuated /filled a minimum of three times, but may be cycled additional times to ensure adverse effects of tritium/oxygen do not result.

- The glovebox shall be designed with waste removal ports that allow heavy waste components/failed equipment to be removed without breaching confinement.

\subsubsection{Structural Support for Equipment}

\section{Requirement}

- PCCS gloveboxes must provide structural support for tritium processing equipment.

\subsubsection{Leak Rates}

\section{Requirements}

- Tritium leaks from sources and primary confinement should be minimized, for example, by using welded connections as much as possible.

- The confinement glovebox systems are to be assembled by manufacturers as it would be installed at APT, with glove ports covers on the glove ports and the bubbler flanges blanked off.

- Confinement gloveboxes are to be helium leak tested, with acceptance criterion being no single leak greater than $10^{-6}$ standard $\mathrm{cm} 3 / \mathrm{s}$ while pressuring to 15 torr above atmospheric.

- Tritium releases to secondary confinement from primary confinement shall be kept to $<0.1 \mu \mathrm{Ci} / \mathrm{cc} / \mathrm{sec}$. 
- Tritium releases to personnel occupied areas from secondary confinement system shall be less than detectable with a tritium "sniffer," or approximately $\leq 4 \times 10^{-5} \mu \mathrm{Ci} / \mathrm{cc}$.

\subsubsection{Monitoring Instrumentation}

\section{Functions}

- The PCCS shall sample and/or monitor tritium, oxygen, moisture, and pressure levels in the confinement system atmosphere.

- The PCCS shall sample gamma radiation, hydrogen and deuterium levels in the confinement system atmosphere, as needed.

\section{Requirements}

- The discharge piping to the stack shall contain redundant activity monitors, one to be on-line and the other in stand-by.

- The activity monitors shall be interlocked to the process stripper system and circulate the gas or shut down the system on high activity.

- Instrument readout system shall be outside the equipment confinement systems in clean areas as much as possible.

- The PCCS shall provide calibration ports along the length of each glovebox to facilitate inline calibration of process instruments.

- The measurement devices shall be constructed of tritium compatible materials and designed to meet the following requirements:

Table 1. PCCS Instrumentation Requirements

\begin{tabular}{|l|c|c|c|c|}
\hline & Tritium & Pressure & Oxygen & Moisture \\
\hline \hline Redundancy & Yes & Yes & No & No \\
\hline Sensitivity & $10^{-4} \mathrm{Ci} / \mathrm{cc}$ & $100 \mathrm{microns}$ & $10 \mathrm{ppm}$ & $10 \mathrm{ppm}$ \\
\hline Range & $0-10^{6} \mathrm{Ci} / \mathrm{cc}$ & $0-2000$ torr & $10 \mathrm{ppm}-1 \%$ & $10-1000 \mathrm{ppn}$ \\
\hline Accuracy & $\pm 10 \mathrm{Ci} / \mathrm{cc}$ & \pm 0.1 torr & $\pm 10 \mathrm{ppm}$ & $\pm 10 \mathrm{ppm}$ \\
\hline
\end{tabular}




\subsubsection{Materials of Construction}

\section{Requirements}

- Materials of construction in tritium containment shall consider guidance found in WSRC-RP-92-431, Tritium Materials Database.

- Suggested compatible materials of construction for PCCS equipment include austenitic 304 stainless steel and aluminum.

- Piping should be standardized with existing stainless steel pipes in 233-H.

- Glovebox panel windows should be Lexan $^{\mathrm{TM}}$, Lucite $^{\mathrm{TM}}$, Plexiglas ${ }^{\mathrm{TM}}$ or tempered, shatter-proof glass.

- Window gaskets may be neoprene or equivalent. Gloves may be butyl rubber or Hypalon $^{\mathrm{TM}}$.

- Use gloves resistant to puncture, moisture and oxygen permeation. Butyl rubber or neoprene are acceptable.

- PVC-base Pylox ${ }^{\mathrm{TM}}$ gloves may be used for enhanced sensitivity applications for work outside of gloveboxes, however, they are not recommended for incineration by the SRS Consolidated Incineration Facility.

- Teflon ${ }^{\mathrm{TM}}$ should be minimized as a material of construction in tritium-wetted applications, and prohibited in applications such as process valve stems/gaskets.

- Materials and components should be rated or designed to protect to the maximum temperature possible during any phase of operation (i.e., system start-up, material activation, routine operation and regeneration).

- The PCCS shall not introduce materials containing hazardous components into gloveboxes.

- The PCCS shall minimize introduction of materials that contain polymeric and other hydrogen-containing materials that readily exchange with tritium inside the confinement system. 


\subsubsection{Human Factors}

\section{Requirements}

- The PCCS shall provide lighting/illumination per OSHA standards; lighting shall be located external to confinement system, if possible.

- The PCCS shall provide alarms to activate on high tritium, oxygen and moisture levels.

- The PCCS shall provide sufficient windows for viewing equipment inside confinement systems.

- The PCCS glovebox interior finish should facilitate decontamination and minimize tritium adhesion.

\subsection{Tritium Stripping Functions and Requirements}

\subsubsection{Tritium Stripping}

\section{Function}

- The PCCS shall provide processes that remove tritium from the confinement system blanket gases.

\section{Requirements}

- The PCCS stripper must be able to process gases from all glovebox atmospheres in the TSF.

- The PCCS stripper must be able to process gases containing mostly nitrogen or argon, and containing small quantities of elemental tritium, tritium water vapor, moisture, oxygen and organic vapors.

\subsubsection{Stackable Tritium Gas Concentration}

\section{Function}

- The PCCS stripper shall remove tritium from glovebox atmosphere gas so that the gas may be discharged directly to stack.

\section{Requirements}

- The TSF shall release less than 10,000 Ci per year during normal operation. 
- The stripper discharge gas must be $<25 \mathrm{ppb}$ tritium in the stripped gases, or less than $0.064 \cdot \mu \mathrm{Ci} / \mathrm{cc}$. This totals approximately $10,000 \mathrm{Ci}$ stack discharge a year, based on assumed $10 \mathrm{cfm}$ purge gas flow rate to stack and 365 days per year of operation.

- Stack purge flow rate shall be minimized as much as possible and limited to $<10 \mathrm{cfm}$

- The stack discharge gas must meet NESHAP Permit limits.

\subsubsection{Stripper Capacity}

\section{Function}

- The PCCS stripper must be designed to reduce tritium concentration from any glovebox, following an accidental tritium release, to a level to allow hands-on processing in 8 hours or less.

\section{Requirements}

- The PCCS stripper must be designed to process at least $200 \mathrm{cfm}$ of glovebox gas.

- Due to its critical nature, the stripper system availability should be at least 300 days a year of 24-hour operation. This capacity assumes that PCCS regeneration and tritium recovery operations can be conducted independently of, and concurrently with, the stripping operation.

\subsubsection{Mode of Operation}

\section{Requirements}

- The PCCS stripper should be designed to operate in continuous circulation operation, per current 233-H practice at SRS.

- The PCCS stripper shall be capable of batch-mode operation, with operation activated by high tritium, moisture or oxygen level.

- Depending on the stripper technology selected, maximize stripper system capabilities, such as water swamping and hydrogen swamping.

\subsubsection{Monitoring Instrumentation}

\section{Function}

- The PCCS shall monitor tritium levels in the tritium stripping systems to permit quantification of system performance. 


\section{Requirements}

- The tritium monitor shall detect to $0.0001 \mathrm{Ci} / \mathrm{cc}$ tritium level with $\pm 5 \%$ accuracy.

- The PCCS stripper system shall be designed for over-pressure and vacuum protection per SRS design standards.

\subsection{Tritium Recovery from Stripper Systems}

\section{Function}

- The PCCS shall provide a process for recovering economical quantities of tritium from the PCCS stripper system.

\section{Requirements}

- The PCCS shall recover at least $90 \%$ of tritium trapped in the PCCS stripper system each "regeneration."

- The PCCS stripper and tritium recovery systems shall be designed for over-pressure and vacuum protection per SRS design standards. 


\section{SURVEY OF TRITIUM CONFINEMENT SYSTEMS}

The open literature was surveyed under the key words: tritium confinement. Articles were identified that deal with three aspects of tritium confinement systems: confinement, blanket gas clean-up or tritium stripping and recovery of tritium from clean-up systems. Other/additional information are based on the authors' visits to LANL, TRL, Mound Plant, Chalk River Lab, and Ontario Hydro.

There appears to be five major types of tritium handling facilities: 1) National Defense Program facilities, 2) Fusion Reactor R \& D facilities, 3) Nuclear Utilities that generate tritium as a by-product, 4) Commercial vendors (e.g. "wholesale”, tritium distributors, tritium light manufacturers), and 5) Universities, hospitals and labs that use tritium in experiments, usually as a tracer. The facilities that handle the most tritium and in the highest concentrations are associated with the Defense Programs and Fusion programs. The notable exceptions are the Canadian tritium recovery facilities and several commercial vendors, such as New England Nuclear and Abbot, that sell tritium tracers to universities and research labs.

Hundreds of papers are published each year discussing the results of using tritium as a tracer, mostly in biochemical and biomedical research. Far fewer are published dealing with the processing and confinement of tritium. The vast majority of the latter are authored by researchers with the Fusion community and the Defense Programs, particularly in the United States. Many tritium confinement papers are presented at the International Tritium Conferences, the proceedings of which are compiled and published in Fusion Technology. Another good journal reference source is the Journal of Vacuum Technology.

Historically, the first tritium process systems utilized the dilute and disperse strategy of tritium confinement. Tritium processing equipment were placed in hoods with high air flow. Most process line and storage tanks operated under vacuum to minimize tritium loss and release. Tritium leaks into the hood are quickly conveyed away by high air flow. The emphasis was on personnel protection. In the seventies and eighties, environmental release concerns also became important. Confinement of process equipment in gloveboxes and other secondary confinements became the accepted norm. DOE tritium facilities adopted secondary and tertiary tritium 
confinement designs. These facilities include the Tritium Research Lab at Sandia-Livermore, the TSTA and WETF at LANL, the T-Building at Mound and the RTF at SRS.

Clean up of confinement or glovebox blanket gas generally used a high temperature catalytic oxidation to oxidize tritium to tritiated water, followed by absorption in a drying material such as zeolite. There are three general dispositions for the tritiated water: 1) disposal by shallow land burial, 2) storage and 3) processing to recover tritium. In the disposal cases, tritiated water was often desorbed from permanent zeolite beds in the tritium stripper system to specially designed disposal absorbent beds. The storage option has been the choice of most tritium facilities in Europe and Japan.

\subsection{Large-Scale Tritium Confinement Systems in Use}

Design, performance data on and descriptions of a number of large-scale tritium handling systems and their confinement systems have been collected. The data is presented in Appendix A. The systems are as follows:

- SRS RTF

- $\quad$ SRS Function Test Facility

- LANL - TSTA

- LANL - WETF

- LANL - TSFF

- SNL-CA - TRL

- $\quad$ Mound - T-Building

- Mound - S/W Building

- Princeton TFTR Tritium Facility

- Chalk River Lab

- Ontario Hydro

- AWE 
The existing RTF at the SRS have the following design features:

1. All tritium processing equipment are confined in gloveboxes.

2. All gloveboxes have nitrogen atmosphere.

3. Glovebox atmosphere gas continuously circulates to one of two Primary Strippers.

4. High activity gloveboxes (up to 3 at one time) are diverted to and cleaned by a Secondary Stripper.

5. Glovebox purge gas is cleaned by a Purge Stripper before discharging to the building stack.

6. Gloveboxes operate at negative pressure relative to process room.

7. Z-beds are regenerated to recover tritium using $\mathrm{Mg}$ beds (originally used $\mathrm{U}$ beds).

Building 233-H operating experience has shown that tritium emission from the building has been reduced greatly compared to the building it replaced. The $\mathrm{Z}$ bed regeneration frequency occurs as anticipated, but the recovery process has been taking longer than expected. Improvements to the RTF system can be made by reducing the frequency of labor-intensive recovery operation and cutting down on recovery cycle time.

The following general observations are made based on the survey of large-scale tritium processing facilities:

1. RTF is the only facility to put all tritium processing equipment in confinement gloveboxes.

2. SRS is the only site to put stripper systems in gloveboxes

3. SRS is the only US site to routinely conduct large-scale recovery of tritium from tritiated water. Other DOE sites in the US bury zeolite beds or send them to the SRS for recovery.

4. LANL TSTA and Princeton TFTR have room air tritium stripper systems

5. LANL and Chalk River Lab operate some tritium gloveboxes under positive pressure to control and minimize moisture and oxygen levels. (The SRS inert metallography facility in 773-A also operates under positive pressure for the same reasons.) 
6. For truly inert equipment blanketing, argon or helium is used in place of nitrogen.

7. The vast majority of glovebox gas stripping systems use the oxidation-absorption process.

8. Different oxidation catalysts are used, $\mathrm{Pd}, \mathrm{Pt}, \mathrm{Cu}, \mathrm{Mn}$, etc., operating over a range of temperatures.

9. Stripper system may operate at several atmosphere pressure to minimize piping size.

10. The few getter stripping systems in routine use are limited to volumetrically smaller gloveboxes. These gloveboxes tend to be operated at positive pressures to the room to minimize moisture and oxygen intrusion. The glovebox atmosphere gas tend to be mostly argon or helium.

11. Hydrogen/tritium getter systems in operation are usually not regenerated for re-use. There is very limited data on getter performance in tritium service following multiple regenerations.

\subsection{Tritium Confinement Technologies}

In general, there are primary confinement systems arid secondary confinement systems. Primary confinement systems consist of equipment such as process piping, valves, tanks, pumps and instrument probe casings that come into direct contact with tritium. Secondary confinement systems are mechanical systems that surround and contain tritium leaks and releases from the primary confinement systems. There are several types of secondary confinement systems, including: glovebox, vacuum jacket, glove bag, airlock, portable airbag, etc.

Confinement systems may be operated under a variety of pressure and atmosphere conditions. The confinement atmosphere gas may be isolated and cleaned only on demand when trigger limits of tritium, oxygen or moisture are exceeded or may re-circulate continuously to a tritium stripping system.

Confinement system design and operation considerations include the need to choose: 1) the type of glovebox atmosphere gas, such as nitrogen, argon or helium; 2) acceptable levels of moisture, oxygen and tritium; 3) between continuous circulating clean-up of glovebox gas vs. batch once through clean-up (for nominally stagnant gloveboxes), and 4) operating the glovebox 
at positive or negative pressure. In general it is desirable to minimize the intrusion of ambient humidity and oxygen into the glovebox. These choices reflect engineering optimization rather than application of new technologies, as in the cases involving clean-up and tritium recovery technologies.

\subsection{Tritium Stripping Technologies}

Tritium that leaks from the primary containment systems into the secondary confinement atmosphere gas is usually removed by a stripper system. The primary functions of a stripper system are to concentrate and recover the tritium, reduce background level of tritium in the confinement system, and reduce worker exposure.

The conventional and most widely used method of removing tritium from confinement atmosphere gas is catalytic oxidation following by absorption in a drying agent such as zeolite. Conventional oxidation-absorption technology is effective, robust, and proven. However, zeolite beds need to be regenerated periodically and elemental tritium is converted to the more toxic oxide form. Other methods of cleaning confinement blanket gas include using 1) getter systems that do not generate tritiated water, 2) wet scrubber systems filled with water, ethylene glycol, or isotopic-exchangeable electrolytes, and 3) palladium membranes/diffusers. In using wet scrubbers, the tritiated liquid must still be disposed of. Earlier R\&D include use of hydrogen uranyl phosphate (HUP) at Lawrence Livermore Laboratory and the use of organic compound TROC processes at the Max Planck - Institute for Plasma Physics (Germany). Areas of active research and development include getters and the palladium membrane/diffusers, both primarily at LANL: Most tritium getters are based on metal hydrides, although there are also solid organic getters.

\subsubsection{Oxidation-Absorption Technology}

In conventional oxidation-absorption stripping technology, the feed gas is processed through a heated catalyst bed $\left(350-500^{\circ} \mathrm{C}\right)$ to convert elemental hydrogens to oxides (waters). The gas is then cooled to $20-30^{\circ} \mathrm{C}$ to absorb the waters in a dessicant, moisture-absorbing material, typically a synthetic zeolite. Tritium in the form of oxide is thus removed from the gas and trapped in the zeolite. Conventional oxidation-absorption technology is efficient, robust, and 
proven. However, zeolite beds become saturated with water and need regeneration, leading to the generation and handling of waste $\mathrm{Mg}$ and $\mathrm{U}$ beds and potential for contamination, etc. Also, elemental tritium is converted to tritium oxide, a much more toxic form of tritium.

Oxidation/absorption performance and design data may be found in several references: Klein and Wermer, 1995, Heung et al., 1992, and Hsu, 1986. A typical process flowsheet using oxidation-absorption for tritium process stripping technology is shown in Figure 2. The catalyst bed is recommended to be $\mathrm{Pd}$ or Pt deposited on an alumina substrate and to operate at $450{ }^{\circ} \mathrm{C}$. The zeolite bed should be designed for operation at $20-30^{\circ} \mathrm{C}$ and equipped with heater system for initial bed activation at $500^{\circ} \mathrm{C}$. Z-bed desorption should be designed for $250{ }^{\circ} \mathrm{C}$ routine operation to effect tritium recovery. A residence time of 2 seconds or more, based on total bed volume, is recommended for the catalyst bed. Catalyst bed cylindrical L/D ratio should be between 3 to 6 . It is not crucial, but should be reasonable to minimize pressure drop and flow channeling. Zeolite bed design should follow manufacturer recommendations for flow rates, residence time, L/D ratio and pressure drops. The final bake-out temperature for the catalyst bed prior to disposal can be the same as the process temperature $\left(500^{\circ} \mathrm{C}\right)$.

Catalyst/zeolite bed equipment sizing data needed, and applicable technical considerations (given in parentheses), are as follows:

1. catalyst bed (residence time, flow rate)

2. zeolite bed (regeneration frequency, flow rate, pressure drop)

3. catalyst bed heater (processing and activation temperatures, type of heater)

4. zeolite bed heater (regeneration and pre-disposal bake-out temperatures)

5. pump size (flow rate, system pressure drop) 


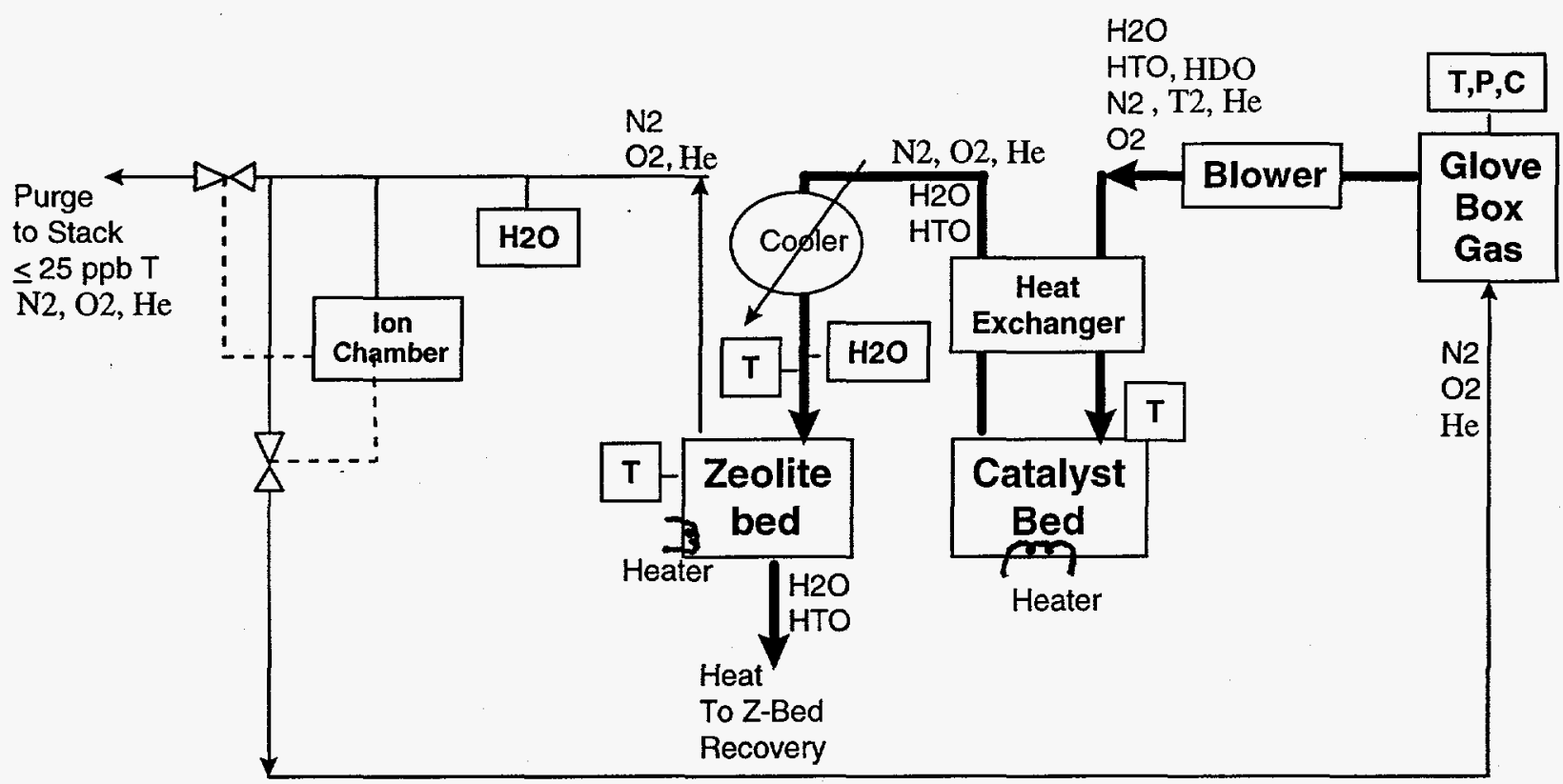

Darker lines indicate tritium-rich streams

Figure 2. PCCS Oxidation-Absorption Process Schematic

\subsubsection{Getter Technology}

In a getter system, tritium and other elemental hydrogen isotopes are gettered from the gas stream on a metallic material as a metal hydride/tritide. The big advantages of getter technology are that getters keep tritium in the elemental form and recovery is accomplished by heating to drive off elemental tritium. Essentially a metal hydride technology, a getter system has all the associated advantages of compact size, simplicity of operation, etc. Getters have been demonstrated for small gas streams at various tritium processing sites such as LANL (TSTA, TSFF), SRS (MTF), AECL, Ontario Hydro, etc. On the basis of a LANL study (Willms and Eaton, 1997) to determine the best alternative technology for stripping of the 233-H NitrogenEvac stream, getter technology was selected as the baseline technology for the TFM \& C Project Tritium Process Stripping System (WSRC, 1997).

Several precautions should be taken with getter technology: 1) Oxygen and moisture negatively impact hydrogen gettering. Sacrificial getter beds are needed to remove oxygen and moisture. Sacrificial beds are removed periodically and disposed of as waste. 2) Nitrogen is not 
inert to certain getters (e.g. SAES $707^{\mathrm{TM}}$ ). 3) Initial preparation and/or regeneration of getters require high temperature $\left(600-650^{\circ} \mathrm{C}\right.$ ) and vacuum (to $\leq 10^{-5}$ torr). 4) Regenerative heating of getter systems should be controlled to minimize material degradation and performance efficiency. Hydrogen getters may disproportionate at elevated temperatures and lose gettering capacity.

Getter performance and design data may be found in several references: 1) Klein and Wermer, 1995, 2) Willms and Eaton, 1997, 3) Shmayda et al., 1992, and 4) Nobile et al., 1995.

A conceptual process schematic using getter technology is shown in Figure 3.

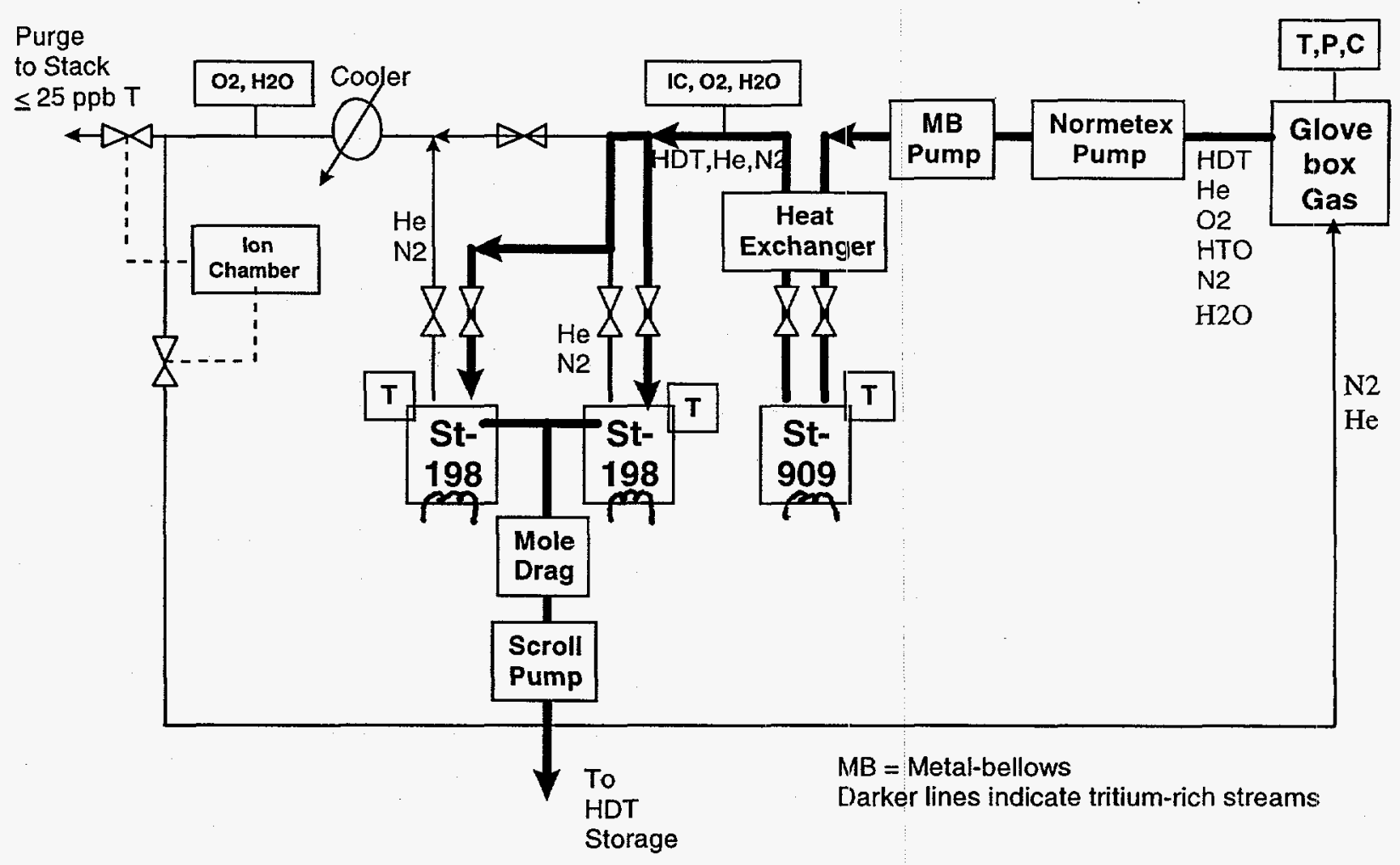

Figure 3. PCCS Getter Process Schematic

Most tritium getter systems use commercially available getters from SAES. The sacrificial SAES 909 bed is recommended to operate at $650^{\circ} \mathrm{C}$ and the hydrogen-gettering SASE 198 bed at $250^{\circ} \mathrm{C}$. Minimum residence times of 2 seconds, based on free bed volume, are recommended. The final bake-out temperature for the SAES 198 getter prior to disposal can be the same as the activation temperature $\left(650^{\circ} \mathrm{C}\right)$. If getter beds are used, tritium recovery involves regenerative 
heating of saturated getters at $\sim 650^{\circ} \mathrm{C}$ under vacuum to drive the tritium off the getter to a storage bed feeding a tritium enrichment system (e.g. TCAP or cryogenic still).

Getter bed heaters should be designed for ease of replacement and to minimize tritium contamination. External heating systems may be preferred. The getter system design in Figure 3 provides for two SAES St 198 tritium getter beds that may operate individually or together in series. Normally one bed is used until it becomes saturated or tritium begins to break through. Then the other bed is valved in, while the saturated bed undergoes regeneration. Similarly, a redundant sacrificial SAES St 909 bed (not shown) may be installed in parallel to minimize downtime.

Getter system equipment sizing data needed, and applicable technical considerations (given in parentheses), are as follows:

1. Hydrogen getter bed size. (Processing flow rate, feed gas composition, hydrogen capacity, regeneration frequency)

2. Getter materials. (Equilibrium hydrogen pressure, getter composition, getter form, cost)

3. Getter heaters. (Activation, processing and regeneration temperatures; presence/absence of vacuum jacket)

4. Pumps. (Processing flow rate and pressure, getter bed and getter system pressure drop)

5. Sacrificial getter bed size. (Flowrate, feed impurities of oxygen and moisture, desired system availability, operating period between change-out, physical size)

\subsubsection{Diffuser Technology}

Diffuser technology is included here only for completeness. No large-scale tritium facility uses diffusers for stripping glovebox atmosphere on a routine basis. Diffusers have a relatively long history of successful application in tritium process separation where the streams are much richer in tritium/hydrogen content (Clark et al., 1995). A heated ( 400 o C) shell-and-tube Pd-Ag diffuser is used to process the gas. Tritium and other hydrogen isotopes diffuse or permeate through the heated tube or coil to the shell or tube while gases such as nitrogen and moisture pass 
undisturbed. Thus diffusers are not capable of effectively stripping tritium in the form of moisture and organics. To use the diffuser process requires pre-treating the feed gas with uranium and zeolite beds to remove oxygen and moisture and a sacrificial Pd/alumina bed to trap any impurities that could react with diffuser tube alloy. Alternatively, a SAES St909 getter bed may be used in place of the sacrificial Pd bed.

\subsubsection{Impact of PCCS Feed Contaminants on Stripper Technology}

The PCCS must be able to achieve the required separation of hydrogen isotopes from inert gases at the required feed rates and in the presence of poteritial feed contaminants. As discussed in Section 2.1.1, several contaminants are expected to be present in the feed to the PCCS: O2, water $(\mathrm{H} 2 \mathrm{O})$, tritiated water (HTO), tritiated organic represented by methane (CQ4) and ammonia represented by NQ3. Their impact on each potential technology is described below:

Oxidation/Absorption: Oxygen and moisture have negligible incremental impact on the system. Higher catalyst temperatures will be required to oxidize methane. More water would lead to greater loading on $\mathrm{z}$-beds. High $\mathrm{H} 2 \mathrm{O}$ content would make recovery less attractive than if HTO content were higher. NQ3 will likely pass through the getter system undisturbed and be stacked.

Getters: Sacrificial getter beds are needed to remove oxygens and convert (crack) waters to elemental hydrogen. Sacrificial beds will have to be disposed. Increased levels of oxygen and water will reduce sacrificial getter life. Getters may crack tritiated organics under reducing conditions. However, CQ4 and NQ3 will likely pass through the getter system undisturbed and be stacked.

Diffusers: Pre-treatment is needed to eliminate oxygen and water and other contaminants. Tritiated water vapor cannot be separated and oxygen will react with hydrogen at the Pd surface. A heated uranium bed may be used to remove oxygen and crack water. A zeolite bed may be used to remove water. A room-temperature Pd/alumina sacrificial getter may be used to trap impurities that could react with the diffuser tube alloy. CQ4 and NQ3 will likely pass through the diffuser system undisturbed and be stacked. The extent of pre-treatment depends on anticipated quantities of contaminants. If feed moisture is low, the zeolite bed my be eliminated. The 
$\mathrm{Pd} /$ alumina bed is capable of trapping small amounts of water. A SAES St909 getter may be used in place of the sacrificial U or Pd bed.

\subsection{Tritium Recovery Technologies}

Tritium recovery from tritiated water generated by the oxidation-absorption process is conducted on a large scale in the DOE Complex only at the SRS. Tritiated water (tritium oxide) is driven off from the z-bed by regenerative heating and reduced over a heated magnesium or uranium bed to release elemental tritium. The SRS tritium recovery process results in the generation of a waste stream of tritium-contaminated spent uranium oxide and magnesium oxide beds. Thus there is a need to periodically dispose of tritium-contaminated uranium/magnesium beds, with associated line breaks, handling of uranium/magnesium bed waste, and the potential for personnel exposure.

Other technologies to recover tritium from tritiated water including liquid electrolysis, solid oxide electrolysis, use of a regenerative iron bed, vapor or liquid phase catalytic exchange and palladium membrane reactor. The Ontario Hydro Darlington Nuclear Generating Station is the other site known to conduct large scale recovery of tritium from tritiated water. Tritium contaminated heavy water moderator is detritiated using distillation, vapor phase catalytic exchange (VPCE) and cryogenic distillation for hydrogen isotopic separation. AECL-Chalk River Lab and Mound Lab have also conducted research into tritium recovery using the Combined Electrolysis and Catalytic Exchange (CECE) process, which combines liquid electrolysis with liquid phase catalytic exchange.

Palladium membrane reactors are under active investigation at LANL. Solid oxide electrolysis and regenerative iron bed are active areas of research and development at SRS. JAERI and LANL also tested a solid oxide electrolysis system in the past. The PMR and Solid Oxide Electrolysis technologies are discussed in more detail below.

\section{Palladium Membrane Reactor}

The palladium membrane reactor (PMR) can be used for the recovery of hydrogen isotopes from compounds such as water and methane. The PMR consists of a shell-and-tube PdAg diffuser with catalyst packed into either the shell or tubes of the diffuser. In the PMR, water is 
reacted with carbon monoxide at elevated temperatures and in the presence of a catalyst to produce elemental hydrogen via the water shift reaction:

$$
\mathrm{H}_{2} \mathrm{O}+\mathrm{CO}=\mathrm{H}_{2}+\mathrm{CO}_{2}
$$

The hydrogen gas is removed by permeation through palladium-silver tubes or membranes. This technology has been under development at LANL for a number of years. A plant-configured prototype needs to be demonstrated with a dilute tritium mixture to obtain data on separation efficiency and for equipment sizing and design. The introduction of CO processing of zeolite bed to complete dryness, and disposition of $\mathrm{CO}_{2}$ must also be addressed. This process will discharge $\mathrm{CO}$ and $\mathrm{CO}_{2}$ to stack and produce a waste stream of failed PMR equipment.

\section{Solid Oxide Electrolysis}

In Solid Oxide Electrolysis, high temperature, gas-phase water vapor is cracked by passage of a current through a solid electrolytic cell. The steam is decomposed into hydrogen and hydroxyl ions which are separated by a ceramic membrane. Hydrogen and tritium ions combine to form elemental hydrogen and tritium gases, which are returned to the primary process. Hydroxyl ions combine to form water and oxygen. Solid Oxide Electrolysis is particularly attractive because the oxygen stream produced is dry and clean, with very low tritium content, which may allow it to be discharged to the stack with minimal treatment. Solid Oxide Electrolysis would therefore reduce or eliminate the need to dispose of tritium-contaminated uranium/magnesium beds. This process will produce waste of failed equipment/components. This technology would reduce the number of line breaks, handling of uranium/magnesium bed waste, and the potential for personnel exposure. 


\section{RECOMMENDATIONS FOR APT-TSF PCCS DESIGN}

The design and operational recommendations proposed for the APT-TSF are shown in the following table. The recommendations are based on industry best practice, standardization with RTF designs/equipment, maturity of improved technology and the results of computer modeling.

The authors recommend that APT tritium processing equipment with $>1000 \mathrm{Ci}$ at risk be confined in gloveboxes, or secondary jackets, in keeping with current SRS practice and As Low As Reasonably Achievable principles. A physically large PCCS stripper system may be located outside of glovebox confinement, if justified by tritium inventory, dose and risk considerations.

It is important to minimize tritium leaks and air/moisture ingress into confinement systems and to avoid the use of hydrogen-exchangeable materials (e.g., cables, insulation) inside the confinement atmosphere. Equipment and process line should be made as leak-tight as possible, at facility start-up and following maintenance. Confinement systems or gloveboxes should be designed to minimize shell penetrations. Oxygen and water intrusion may also be minimized by optimizing the number of gloveports, using moisture/oxygen-resistant gloves and covering gloves when not in use. Gloveport may be designed so that covers may be installed on either the inside or outside of the gloveports. It is recommended that efforts continue to develop glovebox design or identify novel confinement designs to minimize oxygen/water ingress.

For controlling oxygen, the recommended method is using gas purging as is done currently in the RTF. Using oxygen getters such as copper would generate waste beds of volume, weight and handling similar to current RTF Z-bed recovery process. Selective membranes such as used for purifying nitrogen from air may be investigated in the long term as an alternative technology.

Stripping of the glovebox atmosphere gas is recommended to be on a continuous basis. Stripped gas should be circulated to the gloveboxes. Purging of tritium-contaminated gas from confinement atmosphere should be minimized to reduce environmental tritium releases. It is proposed to investigate possibly operating the gloveboxes under both slightly positive or negative pressure relative to the room to reduce the impact of diurnal barometric pressure change on purge 
gas flow, and to minimize leak rate. It is recommended to model glovebox/stripper operation to determine optimal mode of operation.

Based on the conceptual APT process with several water loops, large-scale equipment and susceptibility of confinement system to air/moisture intrusion, and anticipated siting of the APT at the SRS, the recommended stripper technology is the conventional oxidation-absorption process. The advantages of the oxidation-absorption process over getter technology include proven performance, high efficiency, and robustness to handle air/moisture conditions. Getter technology is attractive in that it does not purposely generate tritiated water, but does require a pre-treatment sacrificial getter to remove both oxygen and water. A getter process will thus always generate more sacrificial (and expensive) waste beds than the conventional SRS zeolite bed recovery process using $\mathrm{Mg}$ or $\mathrm{U}$ beds. Getters are also not suited for detritiating airlock flush gas that contains ambient humidity and oxygen. However, getters may still be desirable for specialized applications: i.e., small gloveboxes inerted with $\mathrm{Ar} / \mathrm{He}$, operating under positive pressure with very low intrusion of oxygen and moisture.

No recommendation is made on the preferred tritiurn recovery technology from tritiated water. It is recommended that $\mathrm{R} \& \mathrm{D}$ continue on technologies that may replace the conventional $\mathrm{Mg}$ or $\mathrm{U}$ water cracking process: solid oxide electrolysis and regenerable iron bed technologies at SRS and the palladium membrane reactor (PMR) technology at LANL.

To facilitate open-panel glovebox maintenance, it is proposed to consider designing in glovebox surface decon capability. Since water has been found to be an effective decontamination agent for tritiated surfaces, a water mist sprayer system may be installed. To minimize the potential of an inadvertent release of water to the glovebox, this system could normally be evacuated and blanked out. 
Table 2. Proposed PCCS Design for APT-TSF

\begin{tabular}{|c|c|c|}
\hline $\begin{array}{c}\text { Design Feature/ } \\
\text { Operating Condition }\end{array}$ & Recommendation & Reason \\
\hline Process Equipment & Gloveboxes & DOE Order; $\mathrm{T} 2$ at risk \\
\hline $\begin{array}{l}\text { Stripper System } \\
\text { Confinement }\end{array}$ & $\begin{array}{l}\text { Air Hoods } \\
\text { (if justified) }\end{array}$ & Cost effectiveness; ease of service \\
\hline Mode of Operation & Continuous circulation & $\begin{array}{c}\text { Low background tritium level; } \\
\text { steady-state operation }\end{array}$ \\
\hline Confinement Pressure & $\begin{array}{c}-0.5 \text { in. WC } \\
(+0.5 \text { in WC if needed } \\
\text { for low } \mathrm{O} 2, \mathrm{H} 2 \mathrm{O})\end{array}$ & $\begin{array}{c}\text { To minimize purge gas flow to } \\
\text { stack }\end{array}$ \\
\hline Equipment Blanket Gas & $\mathrm{N} 2$ from liquid N2 & Cost effectiveness \\
\hline Purge Gas Flow Rate & $\sim 10 \mathrm{cfm}$ & $\begin{array}{c}\text { Scaled from RTF stripper system; } \\
\text { To achieve }<10,000 \mathrm{Ci} \text { annual } \\
\text { discharge at } 10 \mathrm{cfm}\end{array}$ \\
\hline Purge Gas tritium Spec & $\begin{array}{c}25 \mathrm{ppb} \\
(0.064 \mu \mathrm{Ci} / \mathrm{cc}) \\
\end{array}$ & $\begin{array}{c}\text { To achieve }<10,000 \mathrm{Ci} \text { annual } \\
\text { discharge at } 10 \mathrm{cfm} \text { to stack }\end{array}$ \\
\hline Stripper System & Oxidation-Absorption & $\begin{array}{l}\text { Robust, proven, demonstrated } \\
\text { RTF experience }\end{array}$ \\
\hline Stripper System Cascàde & $\begin{array}{c}\text { Primary/Secondary/ } \\
\text { Purge }\end{array}$ & RTF experience \\
\hline Catalyst & Engelhard DEOXO-D & RTF experience \\
\hline Catalyst Op. Temp & $350^{\circ} \mathrm{C}$ & RTF experience \\
\hline Zeolite & $3 \mathrm{~A}$ & RTF experience \\
\hline Zeolite Regeneration Temp & $250^{\circ} \mathrm{C}$ & RTF experience \\
\hline $\begin{array}{l}\text { T2 Recovery from } \\
\text { tritiated water }\end{array}$ & $\begin{array}{l}\mathrm{U} / \mathrm{Mg} / \mathrm{PMR} / \text { Solid Oxide } \\
\text { Electrolysis }\end{array}$ & $\begin{array}{c}\text { LANL/SRTC technology } \\
\text { development; } \\
\text { eliminate waste U/Mg beds }\end{array}$ \\
\hline Glovebox Pressure Sensor & Photohelic & RTF experience \\
\hline Glovebox ion chamber & NRC & RTF experience \\
\hline Glovebox moisture sensor & Panametrics & RTF experience \\
\hline Glovebox oxygen sensor & Delta F Corporation & RTF experience \\
\hline Glovebox Temp & Burns Engineering type-J & RTF experience \\
\hline Stripper Gas Blowers & Root & RTF experience \\
\hline
\end{tabular}




\section{Technical Uncertainties, Data Needs and $R \&$ D Opportunities}

In Section 4, R \& D opportunities were identified in the areas of minimizing moisture and oxygen intrusion into gloveboxes, alternatives to gas purging for oxygen control, modeling to optimize strategy or modes of confinement system operation, ways of reducing gas purge due to diurnal pressure change, and technologies for recovering tritium from tritiated water.

As part of the early design input into the Tritium Facilities Modernization and Consolidation Project, several key tritium processing areas were identified as requiring "Alternative Studies" and further Process Development. Cne of these areas is Tritium Process Stripping and Separation from other gases. The approach of the R \& D program is to identify, evaluate and develop improved T2 stripping/separation systems capable of handling future SRS needs in terms of capacity, feed composition, required separation efficiency, etc. A LANL study evaluated a number of alternate technologies to the conventional oxidation-absorption technology: getters, diffusers (permeators), cryogenic adsorption, cryogenic distillation, cryopump, PMR and hollow fiber membrane. Based on that study, getters have been selected as the baseline PCCS technology. However, technical uncertainties remain with respect to their operation under SRS conditions and basic data is needed for design.

SRS and LANL reached agreement in June to collect basic data for PCCS design and for designing a prototype process stripper system for a tritium demonstration (possibly in 232-H) (Motyka, 1997). Data will be collected using a getter system in the TSFF (D. Tuggle) and a twostage diffuser system in the TSTA (S. Willms). Data Needed and proposed experiments are described below.

\subsection{Getter Tests}

A getter bed system using both SAES St 909 and SAES St 198 beds will be designed and connected to the TSFF glovebox at LANL. Gas from the glovebox will be circulated though the getter bed system. The system will be tested to determine the number of times that the SAES St198 tritium getter beds can be loaded and unloaded before replacement is required and to determine the efficiency of hydrogen collection as a function of total gas pressure and hydrogen 
partial pressure in the inlet gas stream, residence time and getter bed temperature. Tritium accountability and St198 getter bed hold-up following each regeneration will be quantified. The effect of water and oxygen concentration on hydrogen collection efficiency and capacity will also be measured. System pumping requirements will be determined. Temperature, pressure and ion chamber tritium measurements will be made throughout the system. Oxygen and water content of the streams feeding and leaving the St198 getter bed will be measured. Final bake-out conditions to prepare the St 198 getter beds for end-of-life disposal and recommended start-up, regeneration and shutdown procedures will be documented.

The LANL getter tests are expected to be completed by the beginning of November 1997. The test results will aid in the final selection of the PCCS technology to be deployed in the TFM \& C Project.

\subsection{Diffuser Tests}

Tritium tests will also be conducted in the TSTA to determine the performance of Pd diffuser (permeator) at low hydrogen partial pressure. The diffuser experiments will use the PMR equipment in the TSTA. The tests will be run over extended periods of time with a number of feed compositions. A baseline test will be run at favorable diffuser temperature (high end) with the best $2^{\text {nd }}$ stage vacuum achievable. The exit concentration will be measured to determine the lowest tritium concentration achievable. Other tests will be run to determine less favorable vacuums, temperatures, at lower tritium feed concentrations and with the introduction of gas impurities.

As with the getter tests, the effect of water and oxygen concentration on diffuser hydrogen separation efficiency and capacity will be measured. System pumping requirements will be determined. Temperature, pressure and ion chamber tritium measurements will be made throughout the system. Recommended start-up, processing and shutdown procedures will be documented.

The LANL diffuser tests are also expected to be completed by the beginning of November 1997. 


\section{REFERENCES}

Abe, T., K. Yamaguchi, H. Kudo, M. Tanase, E.Shikata, H. Umei, K. Tachikawa, and K. Tanaka, 1980. "Development of Tritium Production Technology in Nuclear Fusion Research Program of Japan," US DOE CONF-800427, pp. 367-371, Proceedings Tritium Technology in Fission, Fusion and Isotopic Applications, Dayton, OH, April 29-May 1, 1980

Allsop, P. J. and C. C. Barfoot, 1995a. "Long-Term Performance of Atmospheric-Detritiation Dryers," Fifth Topical Meeting on Tritium Technology in Fission, Fusion and Isotopic Applications, Belgirate, Italy, May 28-June 3, 1995, Fusion Technology, v28, n3, pt2, 1445-1450, October 1995

Allsop, P. J., L. L. Deschenes, B. M. MacDonald, and J. A. Senohrabek, 1995b. "Predicting Detritiation-Dryer Performance at Low Activities" Fifth Topical Meeting on Tritium Technology in Fission, Fusion and Isotopic Applications, Belgirate, Italy, May 28-June 3, 1995, Fusion Technology, v28, n3, pt2, 1451-1456, October 1995

Anderson, J. L., 1980. "Design and Construction of the Tritium Systems Tests Assembly," US DOE CONF-800427, pp. 341-346, Proceedings Tritium Technology in Fission, Fusion and Isotopic Applications, Dayton, OH, April 29-May 1, 1980

Anderson, J. L. and J.R. Bartlit, 1986. "Tritium Fuel Cycle Technology at the Tritium Systems Test Assembly," International Symposium on Fusion Reactor Blanket and Fuel Cycle Technology, Oct 1986

Aytekin, A. and V. Corcoran, 1995. "The Design of the Gas Clean Up System for the New Tritium Facility at AWE Aldermaston," Fifth Topical Meeting on Tritium Technology in Fission, Fusion and Isotopic Applications, Belgirate, Italy, May 28-June 3, 1995, Fusion Technology, v28, n3, pt2, 1463-1468, October 1995

Ballantyne, P. R., A. C. Bell, J. L. Hemmerich, 1992. “The Design Features of Secondary Containments for the JET Active Gas Handling System and Their Role in Mitigating Both Chronic and Accident Tritium Releases," Fourth Topical Meeting on Tritium Technology in Fission, Fusion and Isotopic Applications, Albuquerque, NIM, Sept 29-Oct 4, 1991, Fusion Technology, v21, n2, pt2, 483-488, March 1992

Birdsell, S. A. and R. S. Willms, 1995. "Modeling and Data Analysis of a Palladium Membrane Reactor for Tritiated Impurities Cleanup," Fifth Topical Meeting on Tritium Technology in Fission, Fusion and Isotopic Applications, Belgirate, Italy, May 28-June 3, 1995, Fusion Technology, v28, n3, pt2, 530-537, October 1995

Bruggeman, A. W. Doyen, R. Leysen, L. Meynendonckx, M. Monsecour and W. R. A. Goossens, 1980. "The ELEX Process for Tritium Separation from Aqueous Effluents," US DOE CONF- 
800427, pp. 411-414, Proceedings Tritium Technology in Fission, Fusion and Isotopic Applications, Dayton, OH, April 29-May 1, 1980

Buley, R. D. and D. J. Green, 1995. "Tritium Processing and Confinement at the Savannah River Site," Fifth Topical Meeting on Tritium Technology in Fission, Fusion and Isotopic Applications, Belgirate, Italy, May 28-June 3, 1995, Fusion Technology, v28, n3, pt2, 1307-1311, October 1995

Burdon, J., F. Mannone, A. Aytekin, I. S. Wheelton, 1992. "The Design and Operation of Containments for Tritium Experiments and Their Associated Gaseous Detritiation System in ETHEL," Fourth Topical Meeting on Tritium Technology in Fission, Fusion and Isotopic Applications, Albuquerque, NM, Sept 29-Oct 4, 1991, Fusion Technology, v21, n2, pt2, 352-358, March 1992

Capuder, F. C., R. L. Reece, R. L. Stephenson, W. A. Slusher and W. R. Wilkes, 1980. "Valves and Tritium generators for the TSDS," US DOE CONF-800427, pp. 278-280, Proceedings Tritium Technology in Fission, Fusion and Isotopic Applications, Dayton, OH, April 29-May 1, 1980

Chuang, K. T. and W. J. Holtslander, 1980. "Tritium Transfer Process Using the CRNL Wetproof Catalyst," US DOE CONF-800427, pp. 425-428, Proceedings Tritium Technology in Fission, Fusion and Isotopic Applications, Dayton, OH, April 29-May 1, 1980

Clark, E. A., D. A. Dauchess, L. K. Heung, R. L. Rabun, and T. Motyka, 1995. "Experience with Palladium Diffusers in Tritium Processing," Fusion Technology, v. 28, 566-572, October, 1995

Corcoran, V. J. , T. Aslett, A. Aytekin and A, Huyton, 1995. “A New Containment Box for Tritium Operations," Fifth Topical Meeting on Tritium Technology in Fission, Fusion and Isotopic Applications, Belgirate, Italy, May 28-June 3, 1995, Fusion Technology, v28, n3, pt2, 1321-1326, October 1995

Edwards, R. A. H. and G. Modica, 1995. "Reduction of Tritiated Water on a Regenerable Iron Reactant: Pilot Plant Design," Fifth Topical Meeting on Tritium Technology in Fission, Fusion and Isotopic Applications, Belgirate, Italy, May 28-June 3, 1995, Fusion Technology, v28, n3, pt2, 586-590, October 1995

Ellis, R. E., 1992. "Catalytic Oxidation of Gaseous Organics," Fourth Topical Meeting on Tritium Technology in Fission, Fusion and Isotopic Applications, Albuquerque, NM, Sept 29-Oct 4, 1991, Fusion Technology, v21, n2, pt2, 566-571, March 1992

Fisher, P.W. (ORNL) et al., 1986. “Tritium Pellet Injector Design for Tokamak Test Reactor," 11 th Symposium on Fusion Engineering, CONF-851102-13, 1986 
Futterer, M. A., L. A. Sedano, . L. Giancarli, and E. Proust, 1995. "Tritium Confinement Requirements for the Water-Cooled $\mathrm{Pb}$-17Li Blanket for DEMO" Fifth Topical Meeting on Tritium Technology in Fission, Fusion and Isotopic Applications, Belgirate, Italy, May 28-June 3, 1995, Fusion Technology, v28, n3, pt2, 614-618, October 1995

Gede, V. P. and P. D. Gildea, 1980. "Tritium Practices Past and Present," US DOE CONF800427, pp. 334-340, Proceedings Tritium Technology in Fission, Fusion and Isotopic Applications, Dayton, OH, April 29-May 1, 1980

Gill, J. T., B. E. Anderson, R.A. Watkins, and C. W. Pierce (Mound), 1983. "Tritium storage/delivery and associated clean-up systems for TFTR," J of Vac Science \& Technology A (Vacuum, Surfaces and Films), Proceedings of the 29th National Symposium, v1, n2, pt 2, 85664, April-June 1983

Haange, R., H. Yoshida, O. K. Kveton, J. E. Koonce, H. Horikiri, S. K. Sood, C. Fong, D. Lee, K. M. Kalyanam, and A. Busigin, 1995. "Design of the Atmosphere Detritiation Systems for ITER," Fifth Topical Meeting on Tritium Technology in Fission, Fusion and Isotopic Applications, Belgirate, Italy, May 28-June 3, 1995, Fusion Technology, v28, n3, pt2, 1491-1496, October 1995

Harper, J.R. and R. Garde, 1981. "Decommissioning of a Tritium-Contaminated Laboratory," LA-9056-MS, Nov 1981

Harrison, T. E., 1980. “Design of a Demonstration Tritium Recovery Plant for Chalk River," US DOE CONF-800427, pp. 377-380, Proceedings Tritium Technology in Fission, Fusion and Isotopic Applications, Dayton, OH, April 29-May 1, 1980

Hasegawa, K., K. Horri, M. Matsuyama, and K. Watanabe, 1995. "Applicability of the UVStimulated Oxidation to Tritium Cleanup," Fifth Topical Meeting on Tritium Technology in Fission, Fusion and Isotopic Applications, Belgirate, Italy, May 28-June 3, 1995, Fusion Technology, v28, n3, pt2, 1497-1502, October 1995

Hayashi, T., M. Yamada, T. Suzuki, Y. Matsuda, and K. Okuno, 1995. "Gas Separation Performance of a Hollow-Filament Type Polyimide Membrane Module for a Compact Tritium Removal System," Fifth Topical Meeting on Tritium Technology in Fission, Fusion and Isotopic Applications, Belgirate, Italy, May 28-June 3, 1995, Fusion Technology, v28, n3, pt2, 1503-1508, October 1995

Hedley, W. H., et al., 1992. "Differences Between the TERF and ERS Tritium Capture Systems," Fourth Topical Meeting on Tritium Technology in Fission, Fusion and Isotopic Applications, Albuquerque, NM, Sept 29-Oct 4, 1991, Fusion Technology, v21, n2, pt2, 612-615, March 1992

Heics, A. G. and W. T. Shmayda, 1995. "Design of a Second Generation Secondary Enclosure Clean-Up System," Fifth Topical Meeting on Tritium Technology in Fission, Fusion and Isotopic 
Applications, Belgirate, Italy, May 28-June 3, 1995, Fusion Technology, v28, n3, pt2, 1509-1514, October 1995

Heung, L. K., G. W. Gibson, and M. S. Ortman, 1992a. "Tritium Stripping by a Catalytic Exchange Stripper," Fourth Topical Meeting on Tritium Technology in Fission, Fusion and Isotopic Applications, Albuquerque, NM, Sept 29-Oct 4, 1991, Fusion Technology, v21, n2, pt2, 588-593, March 1992

Heung, L. K., J. H. Owen, R. H. Hsu, R. F. Hashinger, D. E. Ward, and P. E. Bandola, 1992b. "Tritium Confinement in a New Tritium Processing Facility at the SRS," Fourth Topical Meeting on Tritium Technology in Fission, Fusion and Isotopic Applications, Albuquerque, NM, Sept 29Oct 4, 1991, Fusion Technology, v21, n2, pt2, 594-598, March, 1992

Heung, L. K., 1995a. "Stripper System Performance in the Replacement Tritium Facility," Fifth Topical Meeting on Tritium Technology in Fission, Fusion and Isotopic Applications, Belgirate, Italy, May 28-June 3, 1995, Fusion Technology, v28, n3, pt2, 859-864, October 1995

Heung, L. K., 1995b. "Tritiated Ammonia Formation," Fifth Topical Meeting on Tritium Technology in Fission, Fusion and Isotopic Applications, Belgirate, Italy, May 28-June 3, 1995, Fusion Technology, v28, n3, pt2, 1188-1193, October 1995

Hirata, S., T. Takuta, H. Ito, T. Suzuki, T. Hayashi, T. Ishida, Y. Matsuda, and K. Okuno, 1995. "Experimental and Analytical Study on Membrane Detritiation Process" Fifth Topical Meeting on Tritium Technology in Fission, Fusion and Isotopic Applications, Belgirate, Italy, May 28-June 3, 1995, Fusion Technology, v28, n3, pt2, 1521-1526, October 1995

Hsu, R. H., 1986. "Summary of Catalyst and Zeolite Data," DPST-85-869, revised, January 31, 1986

Isles, R., C. Cringan, and F. H. Wu, 1980. "Design Options for Improving Tritium Control at CANDU Nuclear Generating Stations," US DOE CONF-800427, pp. 323-326, Proceedings Tritium Technology in Fission, Fusion and Isotopic Applications, Dayton, OH, April 29-May 1, 1980

Kevton, O. K. , H. Yoshida, J. E. Koonce, R. Haange, H. Horikiri, S. K. Sood, C. Fong, K. M. Kalyanam, and A. Busigin, 1995. "Design of the Water Detritiation and Isotope Separation Systems for ITER," Fifth Topical Meeting on Tritium Technology in Fission, Fusion and Isotopic Applications, Belgirate, Italy, May 28-June 3, 1995, Fusion Technology, v28, n3, pt2, 636-640, October 1995

Klein, J. E. and J. R. Wermer, 1994. "Tritium Stripping in a Nitrogen Glovebox Using SAES 198 (U)," WSRC-TR-94-0416, August 31, 1994 
Klein, J. E. and J. R. Wermer, 1995. "Tritium Stripping in a Nitrogen Glovebox Using Palladium/zeolite and SAES 198," Fifth Topical Meeting on Tritium Technology in Fission, Fusion and Isotopic Applications, Belgirate, Italy, May 28-June 3, 1995, Fusion Technology, v28, n3, pt2, 1532-1539, October 1995

Lamberger, P. H. and M. L. Roger, 1983. Tritium Control: Oct 1982- March 1983, Oct 1983

Lamberger, P. H. and M. L. Roger, 1984. Tritium Control: April-Sept 1983, Jan 1984

Maienschein, J. L., S. W. Wilson, and F. Garcia, 1992. "Design and Operational Experience witha Portable Tritium Cleanup System," Fourth Topical Meeting on Tritium Technology in Fission, Fusion and Isotopic Applications, Albuquerque, NM, Sept 29-Oct 4, 1991, Fusion Technology, v21, n2, pt2, 691-695, March 1992

Maynard, K. J., N. P. Kherani, and W. T. Shmayda, 1995. "Nitridation of Zr2Fe and Its Influence on Tritium Removal" Fifth Topical Meeting on Tritium Technology in Fission, Fusion and Isotopic Applications, Belgirate, Italy, May 28-June 3, 1995, Fusion Technology, v28, n3, pt2, 1546-1551, October 1995

Miller, H.H., E. R. Bissel, R. T. Tsugawa, and P.C. Souers, 1980. "1,4-diphenylbutadiyne as a Potential Tritium Getter," US DOE CONF-800427, pp. 208-212, Proceedings Tritium Technology in Fission, Fusion and Isotopic Applications, Dayton, OH, April 29-May 1, 1980

Mills, T. K., R. E. Ellis and M. L. Rogers, 1980. "Recovery of Tritium from Aqueous Waste Using Combined Electrolysis Catalytic Exchange," US DOE CONF-800427, pp. 422-424, Proceedings Tritium Technology in Fission, Fusion and Isotopic Applications, Dayton, OH, April 29-May 1,1980

Morishita, T., S. Isomura, H. Izawa, and R. Nakane, 1980. "Tritium Removal by Hydrogen Isotopic Exchange Between Hydrogen gas and Water on Hydrophobic Catalyst," US DOE CONF-800427, pp. 415-421, Proceedings Tritium Technology in Fission, Fusion and Isotopic Applications, Dayton, OH, April 29-May 1, 1980

Motyka, T., 1997, Memorandum, Motyka, T. to J. R. Knight, "Tritium Facility Modernization and Consolidation Project, Process Development Plan FY97-98," SRT-CHT-97-0069, June 13, 1997

Munakata, K., K. Takahashi, S. Fukada, N. Nakashio, and M. Nishikawa, 1995. "Removal of Tritium Released into Air by Catalytic Oxidation and Adsorption" Fifth Topical Meeting on Tritium Technology in Fission, Fusion and Isotopic Applications, Belgirate, Italy, May 28-June 3, 1995, Fusion Technology, v28, n3, pt2, 918-923, October 1995

Naito, T., T. Yamada, T. Yamanaka, T. Aizawa, T. Kasahara, M. Nishikawa and N. Asami, 1980, "Design Study of Fuel Circulating System Using Pd-Alloy Membrane Isotope Separation 
Method," US DOE CONF-800427, pp. 233-239, Proceedings Tritium Technology in Fission, Fusion and Isotopic Applications, Dayton, OH, April 29-May 1, 1980

Naruse,Y., K. Tanaka, K. Tachikawa, Y. Matsuda, M. Kinoshita and Y. Obata, 1980 “A Conceptual Design of Tritium Handling Facility,” US DOE CONF-800427, pp. 257-263, Proceedings Tritium Technology in Fission, Fusion and Isotopic Applications, Dayton, OH, April 29-May 1, 1980

Nasise, J. E., 1980. "Performance and Improvements of the Tritium Handling Facility at the Los Alamos Scientific Laboratory," US DOE CONF-800427, pp. 347-352, Proceedings Tritium Technology in Fission, Fusion and Isotopic Applications, Dayton, OH, April 29-May 1, 1980

Nobile, A., T. Bieniewski, K. Frame, R. Little and K. Fisher, 1995 "Design Optimization of Metal Getter Reactors for Removing Tritium from Flowing Streams," Fifth Topical Meeting on Tritium Technology in Fission, Fusion and Isotopic Applications, Belgirate, Italy, May 28-June 3, 1995, Fusion Technology, v28, n3, pt2, 1558-1565, October 1995

Petek, M., D. W. Ramey, R. D. Taylor and E. H. Kobisk, 1980. "Tritium Isotope Separation from Light and Heavy Water by Bipolar Electrolysis," US DOE CONF-800427, pp. 429434, Proceedings Tritium Technology in Fission, Fusion and Isotopic Applications, Dayton, OH, April 29-May 1,1980

Phillips, H., L. Yemin, N. Youssef, C. Pierce, R. Watkins, W. Wilkes and J. Gill, 1980. “Tritium Storage and Delivery System for the Tokamak Fusion Test Reactor," US DOE CONF-800427, pp. 353-359, Proceedings Tritium Technology in Fission, Fusion and Isotopic Applications, Dayton, OH, April 29-May 1, 1980

Rodrigo, L. , J. A. Sawicki, and R. E. Johnson, 1995. "Characterization of Deactivated Metal Getters in a Glovebox Purification System," Fifth Topical Meeting on Tritium Technology in Fission, Fusion and Isotopic Applications, Belgirate, Italy, May 28-June 3, 1995, Fusion Technology, v28, n3, pt2, 1410-1415, October 1995

Schrader, K. H. and A. Perujo, 1995. "Design and Testing of an Advanced Portable Tritium Getter Bed," Fifth Topical Meeting on Tritium Technology in Fission, Fusion and Isotopic Applications, Belgirate, Italy, May 28-June 3, 1995, Fusion Technology, v28, n3, pt2, 1416-1419, October 1995

Schumacher, B. J., 1980. "RTNS-II Tritium Scrubber Design and Performance," US DOE CONF-800427, pp. 267-273, Proceedings Tritium Technology in Fission, Fusion and Isotopic Applications, Dayton, OH, April 29-May 1, 1980

Sheehan, W. E. and D. C. Carter, 1980. "Mound Operational Experience with Tritium Differentiating Ethylene Glycol Air Samplers," US DOE CONF-800427, pp. 175-181, 
Proceedings Tritium Technology in Fission, Fusion and Isotopic Applications, Dayton, OH, April 29-May 1, 1980

Sherwood, A. E., 1980. "Kinetics of Catalyzed Tritium Oxidation in Air at Ambient Temperature," US DOE CONF-800427, pp. 213-218, Proceedings Tritium Technology in Fission, Fusion and Isotopic Applications, Dayton, OH, April 29-May 1, 1980

Shmayda, W. T., N. P. Kherani, B. Wallace and F. Mazza, 1992. "Inert Gas Secondary Enclosure Clean-Up System," Fourth Topical Meeting on Tritium Technology in Fission, Fusion and Isotopic Applications, Albuquerque, NM, Sept 29-Oct 4, 1991, Fusion Technology, v21, n2, pt2, 616-621, March 1992

Smith, P. A., 1996. "An Assessment of the Enclosed Process System Industry in the United States in 1997," December 10, 1996

Sood, S. K., C. Fong, K. M. Kalyanam, K. B. Woodall, and A. Busigin, 1995. "HITEX Process Options for Detritiation of Impurities in the ITER Plasma Exhaust," Fifth Topical Meeting on Tritium Technology in Fission, Fusion and Isotopic Applications, Belgirate, Italy, May 28-June 3, 1995, Fusion Technology, v28, n3, pt2, 742-747, October 1.995

Spagnolo, D. A. and A. I. Miller, 1995. "The CECE Alternative for Upgrading/Detritiation in Heavy Water Nuclear Reactors and for Tritium Recovery in Fusion Reactors" Fifth Topical Meeting on Tritium Technology in Fission, Fusion and Isotopic Applications, Belgirate, Italy, May 28-June 3, 1995, Fusion Technology, v28, n3, pt2, 748-754, October 1995

Tamm, U., E. Hutter, G. Neff and P. Schira, 1992. "Uranium Getters for Tritium Cleanup at the Tritium Laboratory Karlsruhe (TLK)," Fourth Topical Meeting on Tritium Technology in Fission, Fusion and Isotopic Applications, Albuquerque, NM, Sept 29-Oct 4, 1991, Fusion Technology, v21, n2, pt2, 983-987, March 1992

Tanaka, S. and R. Kiyose, 1980. "Catalytic Oxidation of Tritium - Effect of Isotopic Swamping," US DOE CONF-800427, pp. 404-410, Proceedings Tritium. Technology in Fission, Fusion and Isotopic Applications, Dayton, OH, April 29-May 1, 1980

Tuggle, D. and D. A. Lohmeier, 1997. APT Process Confinement and Clean-Up System (PCCS) Description, LANL, 1997

Wall, W. R., R. D. Ristau and P. D. Gildea, 1980. "Control System for Sandia National Laboratories Vacuum Effluent Recovery System," US DOE CONF-800427, pp. 360-366, Proceedings Tritium Technology in Fission, Fusion and Isotopic Applications, Dayton, OH, April 29-May 1, 1980 
Wieneke, R. E., 1992. "Catalytic Reactor System for the Tritium Emissions Reduction Facility," Fourth Topical Meeting on Tritium Technology in Fission, Fusion and Isotopic Applications, Albuquerque, NM, Sept 29-Oct 4, 1991, Fusion Technology, v21, n2, pt2, 577-582, March 1992

Willms, R. S. , S. A. Birdsell and R. C. Wilhelm, 1995. "Recent Palladium Membrane Reactor Development at the Tritium System Test Assembly," Fifth Topical Meeting on Tritium Technology in Fission, Fusion and Isotopic Applications, Belgirate, Italy, May 28-June 3, 1995, Fusion Technology, v28, n3, pt2, 772-777, October 1995

Willms R. S. and L. Eaton, 1997. "Comparison of Methods for Processing the Savannah River Site Tritiated Nitrogen Flush Gas," March , 1997

Wittenberg, L. J., 1978. "Experimental Verification of Tritium Control by Glovebox Containment," Nuclear Technology v 38, p434, May 1978

Wong, D. P., J. L. Hemmerich, and J. J. Monahan, 1992. "The Exhaust Detritiation System forb the JET Active Gas Handling Plant - Engineering, Construction, Installation and First Commission Results," Fourth Topical Meeting on Tritium Technology in Fission, Fusion and Isotopic Applications, Albuquerque, NM, Sept 29-Oct 4, 1991, Fusion Technology, v21, n2, pt2, 572-576, March 1992

WSRC, 1992. “Tritium Materials Data Base,” WSRC-RP-92-431, WSRC, 1992

WSRC, 1997a. Tritium Extraction Facility Design Description, WSRC, 1997

WSRC, 1997b. TEF System Design Description for Process Confinement and Clean-up, Q-SYDH0O003, 1997

WSRC, 1997c. TEF System Design Description for Tritium Recovery Systems, X-SYD-H00006, 1997

WSRC, 1997d. "Tritium Facility Modernization and Consolidation Project, Functional Performance Requirements," P-FPR-H-00001, Rev 2, April 21, 1997

Yamai, H., S. Konishi, M. Hara, K. Okuno, and I. Yamamoto, 1995. "Tritiated Water Processing Using Liquid Phase Catalytic Exchange and Solid Oxide Electrolyte Cell," Fifth Topical Meeting on Tritium Technology in Fission, Fusion and Isotopic Applications, Belgirate, Italy, May 28-June 3, 1995, Fusion Technology, v28, n3, pt2, 1591-1596, October 1995

Yemin, L. and R. Rossmassler, 1980. "Tritium Cleanup Systems for TFTR," US DOE CONF800427, pp. 304-307, Proceedings Tritium Technology in Fission, Fusion and Isotopic Applications, Dayton, OH, April 29-May 1, 1980 


\section{Appendix A Tritium Process Confinement and Clean-up Systems in Use}

There are a number of locations around the world which handle significant quantities of tritium. Their confinement and atmosphere stripper systems are summarized in Table A.1. Their mode of operation: whether these clean-up systems operate batch-wise or continuous, under positive or negative pressure and the type of blanket gas used in the clean-up system glovebox/hood are also indicated. System design, operation and performance collected for each system are described in facility profiles. Missing in this summary are systems used in Germany, Japan, France, Italy and Russia.

Table A.1. Tritium Process Confinement and Clean-up Systems in Use

\begin{tabular}{|c|c|c|c|c|c|c|}
\hline & Location & $\begin{array}{l}\text { Facility } \\
\text { Systems }\end{array}$ & $\begin{array}{c}\text { Batch/ } \\
\text { Continuous }\end{array}$ & $\begin{array}{l}\text { Confinement } \\
\text { Atmosphere }\end{array}$ & $\begin{array}{l}\text { Positive/ } \\
\text { Negative } \\
\text { Pressure }\end{array}$ & $\begin{array}{l}\text { Stripper } \\
\text { Systems }\end{array}$ \\
\hline A. 1 & SRS & 233-H (RTF) & Continuous & $\mathrm{N} 2$ & - & $\begin{array}{l}\text { Oxidation/ } \\
\text { Absorption }\end{array}$ \\
\hline A. 2 & SRS & $\begin{array}{l}\text { MTF Function } \\
\text { Test Facility }\end{array}$ & Batch & $\mathrm{N} 2$ & - & $\begin{array}{l}\text { Oxidation/ } \\
\text { Absorption }\end{array}$ \\
\hline A. 3 & LANL & TSTA & Batch & $\mathrm{N} 2$ & - & $\begin{array}{l}\text { Oxidation/ } \\
\text { Absorption }\end{array}$ \\
\hline A. 4 & LANL & TSFF & Batch & A.r $/ \mathrm{N} 2$ & $+/-$ & $\begin{array}{c}\text { SAES } \\
\text { Getters } \\
\end{array}$ \\
\hline A. 5 & LANL & WETF & Continuous & N2 & - & $\begin{array}{l}\text { Oxidation/ } \\
\text { Absorption }\end{array}$ \\
\hline A. 6 & SNL-CA & TRL & Batch & $A_{\mathrm{r}} / \mathrm{N} 2$ & - & $\begin{array}{l}\text { Oxidation/ } \\
\text { Absorption }\end{array}$ \\
\hline A.7 & Mound & $\begin{array}{l}\text { T-Building/ } \\
\text { SW Building }\end{array}$ & Continuous & $\mathrm{N} 2$ & - & $\begin{array}{l}\text { Oxidation/ } \\
\text { Absorption }\end{array}$ \\
\hline A. 8 & Princeton & TFTR & Continuous & $\mathrm{Ar}$ & - & $\begin{array}{l}\text { Oxidation/ } \\
\text { Absorption }\end{array}$ \\
\hline A. 9 & $\begin{array}{l}\text { Chalk } \\
\text { River }\end{array}$ & CRITIC & Batch & Air & - & $\begin{array}{l}\text { Oxidation/ } \\
\text { Absorption }\end{array}$ \\
\hline A. 10 & $\begin{array}{l}\text { Chalk } \\
\text { River }\end{array}$ & $\begin{array}{l}\text { High-Level/ } \\
\text { HITEX }\end{array}$ & Continuous & Ar & + & $\begin{array}{c}\text { Ti/SAES } \\
\text { Getters }\end{array}$ \\
\hline A.11 & $\begin{array}{l}\text { Ontario } \\
\text { Hydro }\end{array}$ & Tritium Lab & Batch & Arr/N2 & $+/-$ & $\begin{array}{c}\text { Oxidation/ } \\
\text { Absorption; } \\
\text { SAES } \\
\text { getters }\end{array}$ \\
\hline A. 12 & AWE & Tritium Lab & Batch & $\mathrm{N} 2$ & & $\begin{array}{l}\text { Oxidation// } \\
\text { Absorption }\end{array}$ \\
\hline
\end{tabular}




\section{A.1 SRS 233-H (RTF)}

\section{Description:}

All tritium processing equipment in building $233-\mathrm{H}$ are confined in 30 gloveboxes.

Tritium process lines between gloveboxes are jacketed with stainless steel piping. Glovebox blanket gas of nitrogen is continuously recirculated to two (2) primary oxidation/absorption cleanup or stripper system. Elevated tritium activity in glovebox gas will activates glovebox blanket gas flow to a secondary striper for dedicated clean-up. Three gloveboxes may circulate to the secondary stripper at one time. The primary (2) and secondary (1) tritium stripper systems are located inside the largest gloveboxes. The primary stripper purge gas to the $50 \mathrm{ft}$. high building stack is processed through a Pd/zeolite oxidation/absorber Purge Stripper. The purge stripper also cleans antechamber flush gas discharged to stack. Moisture from all three (Primary, Secondary and Purge Stripper) zeolite bed systems is thermally desorbed and processed (reduced) through $\mathrm{Mg}$ beds to recover hydrogen isotopes. Recovered hydrogen isotopes are separated and purified to recover tritium.

\section{Design:}

Glovebox Manufacturer: Custom made by Cryenco, Mueller, and Walker Stainless Steel. Clean-up system: Oxidation-absorption

Once Through/Circulating: Circulating

Capacity: $100 \mathrm{cfm}$ primary/secondary; $10 \mathrm{cfm}$ purge ( $7 \mathrm{cfm}$ design)

Catalyst: Deoxo M

Zeolite: 3A, 4A (purge stripper)

Room clean-up system: No

Oxygen control: Purging; $\mathrm{Cu}$ beds (not used).

Hydrogen swamping: Capability in place, but not used.

Water/Steam swamping: No.

\section{Operating Conditions:}

Glovebox atmosphere: nitrogen

Glovebox pressure: -0.5 " water column differential to room 
Gloves: $30 \mathrm{mil} / 15 \mathrm{mil}$ butyl rubber

Glovebox panel: Plexiglas

Gloveports: 16 per module

Glovebox over-pressure protection: seal pots $( \pm 2$ " water)

Seal pot fluid: silicone fluid

Batch/Continuous: Continuous

Catalyst temp $=425^{\circ} \mathrm{C}$

Regen Z-Bed temp $=250^{\circ} \mathrm{C}$

Regen $\mathrm{Mg}$ Bed temp $=350^{\circ} \mathrm{C}(\mathrm{ck})$

Regen carrier gas: protium

Regen frequency: approx. quarterly

Stripper operating pressure: Ambient.

\section{Performance:}

Tritium: $4-6 \times 10^{-3} \mu \mathrm{Ci} / \mathrm{cc}$

Moisture: 0-4 ppm (post Z-bed)

Oxygen: $0.3-0.5 \%$

Glovebox Background: $0.1-0.3 \mu \mathrm{Ci} / \mathrm{cc}$ (DI GB)

Glovebox background: $0.15-0.4 \mu \mathrm{Ci} / \mathrm{cc}$ (Unloading GB UL-AB)

Glovebox background: $0.009-0.01 \mu \mathrm{Ci} / \mathrm{cc}$ (other gloveboxes)

\section{Waste Streams:}

1. Job control waste (gloves, shoe covers, gaskets, paper)

2. Spent magnesium/depleted uranium beds.

3. Tritium contaminated nitrogen to atmosphere/stack (cleaned).

\section{Comments:}

1. Only stripper systems in the DOE Complex to be located in gloveboxes.

2. Higher moisture loading on $\mathrm{z}$ beds compared to LANL.

3. Most moisture loading from air diffusing into gloveboxes and leaks.

4. Several gloveboxes, either containing high temperature equipment or equipment subject to a large number of connections, have higher tritiurn background levels. 


\section{A.2 SRS MTF Function Test Facility}

\section{Description:}

The SRS Materials Test Facility (MTF) Function Test Facility in building 232-H is composed of two glovebox modules designated as $\mathrm{ABC}$ and DE. Function tests are conducted in a bell-jar inside the gloveboxes. Pipes run between the two glovebox modules, but glovebox atmospheres are isolated from each other. Each module is served by a portable, dedicated $\mathrm{Pd} /$ zeolite stripper system. Glovebox nitrogen blanket gas continuously purges to stack in normal operation. The stripper systems are activated by high tritium concentration, which will turn on compressor and shuts off N2 purge valves to stack. The system is returned to stack purge after low tritium level is achieved ( $<100 \mathrm{Ci}$ inventory in glovebox module blanket gas). The saturated catalyst/dryer bed removed to 232-H Z-bed Regeneration System, where tritium is recovered using $\mathrm{Mg}$ beds. The two stripper systems in the FTF have never been activated in service. Proof of principle tests were conducted in a small nitrogen-blanketed glovebox using a $10 \mathrm{Ci}$ gas mixture.

\section{Design:}

Glovebox Manufacturer: Custom made.

Stripper system: designed by Kevin Reyberger, SRS SRTC/Equipment Engineering.

Clean-up system: Oxidation-Absorption

Once Through/Circulating: Once through normally; Circulating for clean-up.

Capacity: $5 \mathrm{cfm}$ each (Glovebox module volumes are 7,000 1 and 10,500.1, respectively)

Catalyst: Pd dispersed on 4A zeolite beads

Zeolite: $4 \mathrm{~A}$

Size: 15 " L x 5" D; about $20 \mathrm{lb}$. each

Room clean-up system: No.

\section{Operating Conditions:}

Glovebox atmosphere: nitrogen

Glovebox pressure: -0.5 " water column differential to room

Gloves: $30 \mathrm{mil} / 15 \mathrm{mil}$ butyl rubber 
Glovebox panel: Plexiglas

Gloveports: __ per module

Over-pressure protection: seal pots

Seal pot fluid: silicone fluid

Batch/Continuous: Batch

Catalyst temp $=25^{\circ} \mathrm{C}$ (ambient)

Regen Z-Bed temp $=250^{\circ} \mathrm{C}$

Regen $\mathrm{Mg}$ Bed temp $=350^{\circ} \mathrm{C}(\mathrm{ck})$

Regen carrier gas: protium

Regen frequency: as needed.

\section{Performance:}

Tritium: $\times 10^{-3} \mu \mathrm{Ci} / \mathrm{cc}$

Moisture: 5-20 ppm (ck)

Oxygen: $100-1000$ ppm (ck)

Glovebox Background: 0.01-0.1 $\mu \mathrm{Ci} / \mathrm{cc}$

\section{Waste Streams:}

1. Job control waste (shoe covers, gaskets, paper)

2. Spent magnesium/depleted uranium beds.

3. Tritium contaminated nitrogen to atmosphere.

\section{Comments:}

1. Stripper system concept has been patented. 


\section{A.3 LANL Tritium System Test Assembly (TSTA)}

\section{Description:}

Tritium processing equipment are confined in gloveboxes. Cryogenic still hydrogen isotopic separation system is located inside a large vacuum jacket. Lines between gloveboxes jacketed with Tygon/copper tubing. Glovebox atmosphere gas containing tritium dumps to a vacuum tank at $4-13$ psig. At 13 psig, tank content is pumped through a catalyst-dryer system (Tritium Waste Treatment) for clean-up. The exhaust is stacked. Room clean-up system is activated if tritium releases to room. Dryer moisture thermally desorbed from permanent zeolite beds to disposal zeolite beds.

\section{Design:}

Glovebox Manufacturer: Vacuum Atmosphere; custom made

Clean-up system: Oxidation-Drying

Once Through/Circulating: Once Through

Capacity: $40 \mathrm{cfm}$

Catalyst: Deoxo $\mathrm{M}$

Zeolite: $13 \mathrm{X} / 4 \mathrm{~A}$

Room clean-up system: Yes

\section{Operating Conditions:}

Glovebox atmosphere: nitrogen/Ar

Glovebox pressure: -0.5 " water column differential to room

Gloves: $30 \mathrm{mil} / 15 \mathrm{mil}$ Hypalon

Glovebox panel: Plexiglas

Gloveports: 4 per module

Over-pressure protection: seal pots

Seal pot fluid: ethylene glycol

Batch/Continuous: Batch

PMR Loop: $0.51 / \mathrm{min}$ of steam

PMR op. Pressure: (turbo molecular) $10^{-5}$ torr; (scroll pump) 0.2 torr 
PMR op temp : $525 \mathrm{C}$

\section{Performance:}

Tritium: stackable $99.9999 \%$ off blanket gas

$99.7 \%$ removal of high tritium prepared mix.

Moisture: 40-60 ppm glovebox (ck)

Oxygen: $<2-3 \%$

\section{Comments:}

1. Lower moisture loading on $\mathrm{z}$ beds compared to SRS.

2. Load $20 \mathrm{lb}$ water $/ 100 \mathrm{lb}$ disposal zeolite

3. 13 boxes $\times 15 \mathrm{ft} 3 /$ box $\times 10$ gloves/box 


\section{A.4 LANL TSFF}

\section{Description:}

Tritium processing equipment in the Tritium Systems Fabrication Facility (TSFF) are located in gloveboxes. NTTL/TCF/mass spec equipment also located in gloveboxes. Lines between gloveboxes are jacketed with Tygon/copper tubing. Gloveboxes are connected to a 5.7 $\mathrm{m}^{3} / \mathrm{min}$ Gas Purification System (GPS) for maintaining inert atmosphere. The gloveboxes and the GPS are interfaced with an $15 \mathrm{ft}^{3} / \mathrm{min}$ Effluent Treatment System (ETS) designed to remove tritium from al effluents prior to release to environment. The GPS functions have been assumed by a getter system located in a glovebox that is operated as an air box. The GPS and ETS z-bed water is thermally desorbed to disposal zeolite beds.

\section{Design:}

Glovebox Manufacturer: Vacuum Atmosphere; custom made.

Clean-up system: Oxidation/absorption (ETS); Getters

Once Through/Circulating: Once Through (ETS); recirculation (Getters).

Capacity: 15 1/min (Getters)

Catalyst: SAES St $909^{\mathrm{TM}}$, SAES St $198^{\mathrm{TM}}$ getters.

Zeolite: $13 \mathrm{X} / 4 \mathrm{~A}$

Room clean-up system: No.

\section{Operating Conditions:}

Glovebox atmosphere: nitrogen/helium

Glovebox pressure: +0.5 " water column differential to room (for dry box)

Gloves: 15-mil Hypalon (chloro-sulfonated polyethylene)

Glovebox panel: Plexiglas

Glove ports: __ per module

Over-pressure protection: seal pots $( \pm 10$ " water)

Seal pot fluid: oil

Batch/Continuous: continuous

SAES St909 operating temp: $600-650^{\circ} \mathrm{C}$ 
SAES St 198 operating temp: $250^{\circ} \mathrm{C}$

\section{Performance:}

Tritium: $<0.7 \mu \mathrm{Ci} / \mathrm{cc}$ (getter); $<1 \mathrm{ppm}(12.5 \mu \mathrm{Ci} / \mathrm{cc})$ for ETS.

Moisture: 40-60 ppm

Moisture: $<0.5 \mathrm{ppm}$ for dry box

Oxygen: $<100 \mathrm{ppm}$

Oxygen: $<1 \mathrm{ppm}$ (positive pressure glovebox)

Moisture: $<15 \mathrm{ppm}$ (positive pressure glovebox)

Year put in Service (GPS/ETS): 1974

\section{Waste Streams:}

Job control waste (gloves, gaskets, ...)

Tritium contaminated nitrogen to stack.

Tritiated water to 30 gal disposal zeolite beds, packed in vermiculite.

Sacrificial SAES St198 beds

\section{Comments:}

1. Lower moisture loading on $\mathrm{z}$ beds compared to SRS.

2. Zeolite beds to be calorimetered for tritium content in the future.

3. GPS/ETS use Hoke valves with Teflon seats.

4. Also use Cajon compression coupling with nickel gaskets.

5. Oxygen removed by copper bed.

6. Getter operation following regeneration needs to be established. 


\section{A.5 LANL Weapons Engineering Tritium Facility (WETF)}

\section{Description:}

Tritium unloading, processing, loading and function test equipment are in gloveboxes. Lines between gloveboxes are jacketed with Tygon/copper tubing. Glovebox atmosphere gas dumps to a vacuum tank at 4-13 psig when tritium concentration exceeds trigger level. At 13 psig, tank content is pumped through a oxidation-absorption system (Tritium Waste Treatment System) for clean-up. The exhaust is stacked. Room air clean-up system is activated if tritium releases to room. Dryer moisture thermally desorbed to disposal zeolite beds.

\section{Design:}

Glovebox Manufacturer: Vacuum Atmosphere.

(Function Tester-Stainless Equipment Co.)

Glovebox material of construction: 3/16" type 6061 aluminum; 300 SS connections

Clean-up system: Oxidation-Drying

Once Through/Circulating: Once Through

Capacity: $4 \mathrm{cfm}$

Catalyst: Deoxo $\mathrm{M}$

Zeolite: $13 \mathrm{X} / 4 \mathrm{~A}$

Room clean-up system: Yes

N2 supply line: type $\mathrm{K}$ copper

TWTS piping: $1 \frac{1 / 2}{2}$ ' to low pressure receiver (LPR); $1 / 2$ " purge outlet

Antechambers: 15"Dx24"L (Process); 18"x34"L (FT)

Antechamber op vacuum: $200-400$ torr

\section{Operating Conditions:}

Glovebox atmosphere: nitrogen ( $>2 \%$ purge to $L P R$ )

Glovebox pressure: \pm 1 torr differential to room

Gloves: 30 mil Hypalon

Glovebox panel: Lexan

Glove ports: 4 per module 
Over-pressure protection: seal pots (relieves at \pm 8 " water)

Seal pot fluid: ethylene glycol

Batch/Continuous: Batch

N2 flush to glovebox: $\sim 1 \mathrm{cfm}$

\section{Performance:}

Tritium: $<10^{-3} \mu \mathrm{Ci} / \mathrm{cc}\left(<1 \mathrm{mCi} / \mathrm{m}^{3}\right)$

Moisture: $40-60 \mathrm{ppm}$

Oxygen: $<2 \%$

Glovebox leak spec: single leak $<3 \times 10^{-8} \mathrm{std} \mathrm{cm}^{3} / \mathrm{s}$.

Pressure: \pm 0.1 torr

\section{Waste Streams:}

1. Job control waste (gloves, gaskets, etc.)

2. Tritium contaminated nitrogen to stack. .

3. Tritiated water to disposal zeolite beds.

\section{Comments:}

1. Lower moisture loading on $\mathrm{z}$ beds compared to SRS. 


\section{A.6 SNL-CA Tritium Research Laboratory (TRL)}

\section{Description:}

Tritium unloading, processing, loading and function test equipment in sealed, stainless steel gloveboxes. Lines between gloveboxes jacketed with Tygon/copper tubing. Gloveboxes may be operated with N2 or Ar blanket gas or as air hood. Gloveboxes normally stagnant. Blanket gas is cleaned by the Gas Purification system (GPS). There is also a Vacuum Effluent Recovery System (VERS) for process line flushes and pump down gas. Both use the same stripper technology. The exhaust gas is stacked. Dryer moisture thermally desorbed to disposal zeolite beds. Clean-up stripper systems are not confined in gloveboxes.

\section{GPS Design:}

Glovebox Manufacturer: Custom Made.

Glovebox material of construction: SS; 300 SS connections

Clean-up system: Oxidation-Absorption.

Once Through/Circulating: Both capabilities.

Capacity: $340 \mathrm{~m}^{3} / \mathrm{hr}$.

Catalyst: Engelhard A-16648 at $783^{\circ} \mathrm{K}$ for methane.

Zeolite: 4A. 37 mole water capacity at $1 \mathrm{ppm}$ gas out.

Room clean-up system: No

Redundancy: blowers, heaters, catalyst beds, dryer beds.

\section{Operating Conditions:}

Glovebox atmosphere: N2/argon

Glovebox pressure: -0.25 to $-1.0 \mathrm{kPa}$ to room

Gloves: 30 mil Hypalon (ck)

Glovebox panel: Lexan (ck)

Glove ports: 8 per module (ck)

Over-pressure protection: seal pots (relieves at \pm 8 " water) (ck)

Seal pot fluid: ethylene glycol

Batch/Continuous: Batch 


\section{Performance:}

Tritium: $<10^{-3} \mu \mathrm{Ci} / \mathrm{cc}\left(1 \mathrm{mCi} / \mathrm{m}^{3}\right)(\mathrm{ck})$

Moisture: $40-60 \mathrm{ppm}$ (ck)

Oxygen: <_ ppm

Glovebox leak spec: single leak $<3 \times 10^{-8} \mathrm{std} \mathrm{cm}^{3} / \mathrm{s}$.

Pressure: -0.25 to $-1.0 \mathrm{kPa}$ to room.

Year put in operation: 1977

\section{Waste Streams:}

1. Job control waste (gloves, gaskets, etc.)

2. Tritium contaminated argon/nitrogen to stack.

3. Tritiated water to disposal zeolite beds.

\section{Comments:}

1. Separate blowers for stripping and dryer regeneration.

2. Moisture swamping for downstream dryers. 


\section{A.7 Mound Lab T-Building/SW Building}

\section{Description:}

Tritium unloading, processing, loading and function test equipment in gloveboxes. Glovebox atmosphere gas is pumped through a oxidation-absorption system (Tritium Effluent Removal Facility) for clean-up. The exhaust is stacked. Room clean-up system is activated if tritium releases to room. Dryer moisture thermally desorbed to disposal zeolite beds. The TBuilding claims triple containment for Savannah River Operations Contingency (SROC) systems. The SW/R building claims double containment.

Mound Lab has two stripper systems in the T-Building: 1) Tritium Emission Reduction Facility (TERF), and the Tritium Aqueous Waste Recovery System (TAWRS). There is one system in the Semi-Works/Research (SW/R) Building: Effluent Removal System (ERS)

\section{Design:}

Glovebox Manufacturer: Mound Laboratory.

Glovebox material of construction: TERF: Inconel 625/316L ss; ERS: 304H ss.

Clean-up system: Oxidation-Absorption

Once Through/Circulating: Once Through

Capacity: $80 \mathrm{cfm}$ TERF; $35 \mathrm{cfm}$ (ERS)

Catalyst: Hopcalite/Engelhard 16,648 Pt/Al2O3

Zeolite: 4A

Room clean-up system: No

Antechambers: 15'Dx24'L (ck)

Antechamber op vacuum: $200-400$ torr (ck)

Pre-treatment: Refrigerated filter at $223 \mathrm{oK}(-50 \mathrm{oC})$

Surge Tank: 45,000 liter (ERS)

\section{Operating Conditions:}

Glovebox atmosphere: nitrogen (ck)

Glovebox pressure: \pm 1 torr differential to room

Gloves: rubber 
Glovebox panel: Safety plate glass

Glove ports: __ per module

Catalyst temp: $400 \mathrm{oC}$ max for hopcalite; $400 \mathrm{oC}$ minimum for $\mathrm{A} 16,648$

$\mathrm{Z}$ bed regen frequency: Daily (ERS); as-needed (TERF)

Operating Pressure: 50-100 psig (TERF); 10 psig (ERS)

Over-pressure protection: seal pots (relieves at \pm 8 " water) (ck)

Seal pot fluid: ethylene glycol (ck)

Batch/Continuous: Continuous

N2 flush to glovebox: $\sim 1 \mathrm{cfm}$

\section{Performance:}

Tritium in glovebox: $<15 \mathrm{ppm}$ or $\sim 40 \mu \mathrm{Ci} / \mathrm{cc}\left(40 \mathrm{mLi} / \mathrm{m}^{3}\right)$

Tritium out of stripper: $<1 \mathrm{ppb}$

Moisture: 40-60 ppm (ck)

Oxygen: $<2 \%$ (ck)

Glovebox leak spec: single leak $<3 \times 10^{-8} \mathrm{std} \mathrm{cm}^{3} / \mathrm{s}$.

Pressure: \pm 0.1 torr

\section{Waste Streams:}

1. Job control waste (gloves, gaskets, etc.)

2. Tritium contaminated nitrogen to stack.

3. Tritiated water/organic condnsate to disposal packages.

4. Tritiated water is mixed/stabilized with cement for disposal. Tritium recovery using CECE is possible.

\section{Comments:}

1. Mound stacks gas emission at 3-5 mCi/m3 tritium in 1974 (ref: Sheehan/carter).

2. The TERF operates at elevated pressure compared to the ERS.

3. The TERF System lines outside gloveboxes are double-contained; the ERS is not.

4. The TERF system is designed to recover heat from compressors and heated gas. 


\section{A.8 Princeton Tokamak Fusion Test Reactor (TFTR) Tritium Facility}

\section{Description:}

The Tokamak Fusion Test Reactor (TFTR) is a project undertaken in the Princeton Plasma Physics Lab (PPPL). TFTR uses a tokamak to conduct fusion research. Tritium unloading, fuel injection, purification and processing equipment are located in gloveboxes. The glovebox blanket gases are cleaned in stripper systems. Stripper systems are located in the room. Lines between gloveboxes are welded stainless steel pipes. The exhaust is stacked. Room cleanup system is activated if tritium is released to room.

TFTR has three distinct clean-up stripper systems:

- Tritium Vault Clean-up System (TVCS) cleans up the room atmosphere in case of release to tritium vault room. Re-designed to clean-up TVCS room also. Cleaned gas is discharged to one corner of the same room. Room is isolated from building stack during operation of the room clean-up system. Due to moisture in room air, duration of TVCS operation is limited by zeolite bed capacity to $\sim 8$ hours.

- Torus Clean-up System (TCS) cleans up the torus gas during tritium testing. Designed by Ontario Hydro. U bed to remove $\mathrm{H} 2$ designed by Ontario Hydro failed in testing. Use RSI diffuser instead. T2 collected on cryogenic panel. Torus decontamination now scrubs gas through 55 gallon drum of water.

- Tritium Storage and Delivery Clean-up System (TSDCS) continuously clean up tritium from glovebox housing tritium source in UC-609 container or uranium bed. UC-609 glovebox is blanketed with nitrogen. $\mathrm{U}$ bed glovebox is blanketed with high purity argon $(<0.1 \mathrm{ppm} \mathrm{O})$. 


\section{Design:}

\begin{tabular}{|c|c|c|c|}
\hline & TVCS & TCS & TSDCS \\
\hline Glovebox Manufacturer: & N/A & Mound Lab & Mound Lab \\
\hline $\begin{array}{l}\text { Glovebox material of } \\
\text { construction: }\end{array}$ & N/A & $\begin{array}{l}304 \text { ss welded, } \\
\text { VCR fittings }\end{array}$ & $\begin{array}{l}304 \text { ss welded, } \\
\text { VCR fittings }\end{array}$ \\
\hline Clean-up system: & Oxidation-Drying & Oxidation-Drying & Oxidation-Drying \\
\hline Once Through/ Circulating: & $\begin{array}{l}\text { Recirculate to room } \\
\text { (limited to } \sim 8 \mathrm{hr} \\
\text { operation) }\end{array}$ & Circulating & Reciculating \\
\hline Capacity: & $1000 \mathrm{cfm}$ & $50 \mathrm{cfm}$ & $10 \mathrm{cfm}$ \\
\hline Catalyst: & $\mathrm{Pd} / \mathrm{Pt}$ on alumina & $\mathrm{Pd} / \mathrm{Pt}$ on alumina & $\mathrm{Pd} / \mathrm{Pt}$ on alumina \\
\hline Zeolite: & $\begin{array}{c}4 \mathrm{~A} ; 2 \text { beds } \\
3000 \text { lbs total }\end{array}$ & $\begin{array}{c}4 \mathrm{~A} ; 2 \text { beds in } \\
\text { parallel; } 1 \text { in series } \\
500 \mathrm{lbs} \text { total or } \\
\text { each? }\end{array}$ & $4 \mathrm{~A} ; 100 \mathrm{lbs}$ total \\
\hline N2/Ar supply line: & N/A & type $K$ copper & type K copper \\
\hline Piping: & $12 "$ to/from room & $\begin{array}{l}\text { 2" to/from } \\
\text { glovebox }\end{array}$ & $\begin{array}{l}1 / 2 " \text { to/from } \\
\text { glovebox }\end{array}$ \\
\hline Antechambers: & N/A & $15^{\prime \prime} \mathrm{D}$ X 24" L & $15^{\prime \prime} \mathrm{D} \times 24 " \mathrm{~L}$ \\
\hline $\begin{array}{l}\text { Antechamber operating } \\
\text { vacuum: }\end{array}$ & N/A & 10 torr? & 10 torr? \\
\hline
\end{tabular}




\section{Operating Conditions:}

\begin{tabular}{|l|c|c|c|}
\hline & TVCS & TCS & TSDCS \\
\hline Glovebox Atmosphere: & N/A & N2/Ar & N2 \\
\hline Glovebox pressure & N/A & $-1.0^{\prime \prime}$ water & $-1.0^{\prime \prime}$ water \\
\hline Gloves: & N/A & 30 mil Hypalon & 30 mil Hypalon \\
\hline Glovebox Panel & N/A & Lexan & Lexan \\
\hline Gloveports & N/A & 4 per module & 4 per module \\
\hline Catalyst temp & $25^{\circ} \mathrm{C}$ & $500^{\circ} \mathrm{C}$ & $500^{\circ} \mathrm{C}$ \\
\hline Zeolite regeneration & $400^{\circ} \mathrm{C} \mathrm{N} 2$ gas & $400^{\circ} \mathrm{C} \mathrm{N2}$ gas & $400^{\circ} \mathrm{C}$ N2 gas \\
\hline Over-pressure Protection: & N/A & sealpot $\pm 6^{\prime \prime}$ water $)$ & sealpot $\pm 6^{\prime \prime}$ water $)$ \\
\hline Seal pot fluid & N/A & synthetic oil & synthetic oil \\
\hline Batch/Continuous & Continuous & Continuous & Continuous \\
\hline Blanket Gas Flow Rate & $1000 \mathrm{cfm}$ & $50 \mathrm{cfm}$ & $10 \mathrm{cfm}$ \\
\hline
\end{tabular}

\section{Performance:}

Tritium: $150-200 \mu \mathrm{Ci} / \mathrm{m} 3$

Moisture: Not measured ("dry")

Oxygen: $<2000$ ppm

Glovebox leak spec: ?? single leak $<3 \times 10^{-8} \mathrm{std} \mathrm{cm}^{3} / \mathrm{s}$.

Pressure: \pm 0.1 torr

\section{Waste Streams:}

1. Job control waste (gloves, gaskets, etc.)

2. Tritium contaminated nitrogen/argon to stack.

3. Tritiated water to Type B zeolite beds $(\geq 1000 \mathrm{Ci}$ ) for shipping to SRS for T2 recovery.

4. Tritiated water to Type A disposal zeolite beds (<1000 Ci) for shipping to Hanford for disposal. 


\section{Comments:}

1. Room Clean-up cleans up vaults/glovebox room, gas holding tank room; room cleanup system room.

2. TFTR has $5 \mathrm{gm}$ T2 SAR limit.

3. $\mathrm{Cu}-\mathrm{CuO}$ bed originally to remove unreacted $\mathrm{O} 2$ to $<0.1 \mathrm{ppm} \mathrm{O} 2 \mathrm{spec}$ in Argon. glovebox; hard to maintain after start-up, later raised or shown to be allowed to rise (now to $\sim 2000 \mathrm{ppm}$ ).

4. UC-609 T2 in nitrogen box; U-bed $\mathrm{T} 2$ source in argon glovebox.

5. Tritium reacts with hydrogen hexafluoride (used in Torus experiment) to form corrosive HF.

6. Argon box has dedicated clean-up system.

7. Room lean-up system recirculates to corner of room.

8. Humidity clean-ups up glovebox surface well.

9. $2 \mathrm{gm}$ tritium inventory is estimated to be tied up in the torus.

10. Tritiated gas leaving torus scrubbed in 55 gal drum of water.

11. Large portable $\mathrm{z}$-beds designed to fit in UC-609 container.

12. Type $13 \mathrm{X}$ zeolite absorbs HF6 better than $4 \mathrm{~A}$.

13. Cryogenic distillation provides final separation.

14. N2 supplied from 40 psig liquid N2. Compressed N2 in cylinders is available as back-up. 


\section{A.9 Chalk River CRITIC Glovebox}

\section{Description:}

Tritium extraction equipment in gloveboxes. Line (1/8" or 1/4") from NTU reactor to lab, welded and traced o prevent moisture condensation. Glovebox is operated as a hood under negative pressure. Discharges to building stack. Process T2 stripper system uses a CuO catalysts and Dryerite ${ }^{\mathrm{TM}}$ to trap tritium.

\section{Design:}

Glovebox Manufacturer: Custom made.

Glove box material of construction:

Clean-up system: None.

Once Through/Circulating: Once Through

Capacity: N/A

Catalyst: $\mathrm{CuO}$ for process stripper.

Desiccant: Drierite ${ }^{\mathrm{TM}}$.

Room clean-up system: No

\section{Operating Conditions:}

Glovebox atmosphere: air

Glovebox pressure: - 2" differential to room

Gloves: 30 mil Hypalon?

Glovebox panel: Lexan

Glove ports: 4 per module

Over-pressure protection: N/A

Seal pot fluid: ethylene glycol

Batch/Continuous: Continuous

N2 flush to glovebox: N/A

\section{Performance:}

Tritium: $10^{-3} \mu \mathrm{Ci} / \mathrm{cc}\left(1 \mathrm{mCi} / \mathrm{m}^{3}\right)$ 
Moisture: $40-60 \mathrm{ppm}$

Oxygen: $<0.2 \%$

Glovebox leak spec: single leak $<3 \times 10^{-8} \mathrm{std} \mathrm{cm}^{3} / \mathrm{s}$.

Pressure: \pm 0.1 torr

\section{Waste Streams:}

Job control waste (gloves, gaskets, etc.)

Tritium contaminated air to stack.

Tritiated water in Dryerite to disposal.

\section{Comments:}




\section{A.10 Chalk River High-Level Tritium/HITEX Glovebox}

\section{Description:}

Tritium unloading and loading equipment in a glovebox. Tritium from transport $U$ beds unloaded to U beds. P-V-T and metered to smaller U beds for shipment to commercial customers such as tritium light manufacturers. Lines between glovebox and clean-up systems stainless steel pipe. Ar gas glovebox atmosphere. Operated at positive +2 " pressure. System licensed for 1,000,000 Ci. Glovebox blanket gas is pumped continuously to two Ti beds for clean-up. During unloading of tritium from transport $\mathrm{U}$ beds, tritium level rises in Glovebox. A bleed stream is manually turned on to a getter clean-up system. SAES 707 Getter. Moisture and oxygen impurity removed by the getter. Saturated Ti beds disposed as waste. No tritium recovery. The HITEX system is undergoing testing. Glovebox is operated as hood. Will be operated like the High-level glovebox once tritium is introduced.

\section{Design:}

Glovebox Manufacturer: Custom.

Glovebox material of construction: ss.

Clean-up system: Ti/SASE getters

Once Through/Circulating: Circulating.

Capacity: $4 \mathrm{cfm}$ ?

Catalyst: N/A

Zeolite: N/A

Room clean-up system: No

Ar supply line: ss

Antechambers: 15'Dx24"L (ck)

Antechamber operating vacuum: $200-400$ torr

\section{Operating Conditions:}

Glovebox atmosphere: argon

Glovebox pressure: +2" differential to room

Gloves: 30 mil Hypalon? 
Glovebox panel: Lexan

Glove ports: 4 per module

Over-pressure protection: seal pots (relieves at \pm 8 " water)

Seal pot fluid: ethylene glycol (ck)

Batch/Continuous: Continuous

Ar flush to glovebox: $\sim 1 \mathrm{cfm}$

\section{Performance:}

Tritium: $10^{-3} \mu \mathrm{Ci} / \mathrm{cc}\left(1 \mathrm{mCi} / \mathrm{m}^{3}\right)$ (ck)

Moisture: $40-60 \mathrm{ppm}\left(-60^{\circ} \mathrm{C}\right.$ dewpoint)

Oxygen: < anticipated to be same as high-level glovebox system

Glovebox leak spec: single leak $<3 \times 10^{-8} \mathrm{std} \mathrm{cm}^{3} / \mathrm{s}$.

Pressure: \pm

\section{Waste Streams:}

1. Job control waste (gloves, gaskets, etc.)

2. Tritium contaminated argon to stack.

3. Tritiated water/oxygen to SASE getter to disposal.

4. Deactivated Ti beds to disposal.

\section{Comments:}

1. Positive pressure glovebox; system licensed for $1,000,000 \mathrm{Ci}$; no tritium recovery. 


\section{A.11 Ontario Hydro}

\section{Description:}

Ontario Hydro tritium lab operates several small gloveboxes for different experiments.

The glovebox atmosphere is either argon or nitrogen, depending $\mathrm{n}$ the experiment. Getter types of stripper systems are used to remove tritium from glovebox atmosphere.

\section{Design:}

Glovebox Manufacturer: Not clear.

Glovebox material of construction: SS.

Clean-up system: Getters.

Once Through/Circulating: Once through.

Capacity:

Catalyst: SAES getters

Zeolite: Not used.

Room clean-up system: No

\section{Operating Conditions:}

Glovebox atmosphere: nitrogen/Ar

Glovebox pressure: $+/$ - differential to room

Gloves:

Glovebox panel:

Glove ports:

Over-pressure protection:

Seal pot fluid:

Batch/Continuous: Batch

Getter temp $=$ ${ }^{\circ} \mathrm{C}$

Getter regeneration temp $=$ ${ }^{\circ} \mathrm{C}$

\section{Performance:}

Tritium: low $=1.26 \mathrm{~Bq} / \mathrm{m} 3 \rightarrow$ Purge ??

$$
\text { Medium }=6.7 \mathrm{GBq} / \mathrm{m} 3 \rightarrow \text { Purge ?? }
$$




$$
\text { High }=\gg>\quad ? ?
$$

Discharge $<8 \mathrm{MBq} / \mathrm{m} 3$ for discharge or $<\quad \mu \mathrm{Ci} / \mathrm{cc}$ ??

Moisture: $\quad$ ppm (post Z-bed) ??

Oxygen: Low limit: 100 ppm ??

High Limit: 1000 ppm ??

Glovebox Background: $\mu \mathrm{Ci} / \mathrm{cc}$ ??

\section{Waste Streams:}

1. Job control waste (gloves, gaskets, etc.)

2. Tritium contaminated argon to stack.

3. Tritiated water/oxygen to SASE getter to disposal.

4. Deactivated Ti beds to disposal.

\section{Comments:}

1. Small gloveboxes are in use. Glovebox condition and clean-up systems are operated to suit specific experimental needs. 


\section{A.12 AWE}

\section{Description:}

New facility under design (Aytekin and Corcoran, 1995). The overall system consists of a Gas Collection System, a Waste Recovery System, and a Waste Conditioning Unit. Equipment in 15 gloveboxes, $8 \mathrm{~m}^{3}$ each. Glovebox atmosphere cooled to $30-35^{\circ} \mathrm{C}$. Nitrogen or argon glovebox atmosphere. Glovebox atmosphere gas is static unless O2, HTO, or T2 detected. Glovebox atmosphere is then recirculated to catalyst-dryer clean-up system (Gas Clean Up System) until tritium content is sufficiently low to allow stacking. HTO removed to disposal dryer beds (zeolite). Tritium is not recovered.

(Note: $1 \mathrm{GBq}=27 \mathrm{mCi}$ )

\section{Design:}

Glovebox Manufacturer: TBD; part materials 304/316 ss.

Clean-up system: Oxidation-Absorption

Once Through/Circulating: Recirculated until acceptable for discharge; feed gas from an accumulator; operates in batch mode.

Capacity: $72 \mathrm{~m} 3 / \mathrm{h}$ or $300 \mathrm{~m} 3 / \mathrm{h}$ (?) peak capacity.

Catalyst: Deoxo D 4586; 50 kg @ 500 oC

Swamping capability: Hydrogen and oxygen

Zeolite: $4 \mathrm{~A} ; 50 \mathrm{~kg}$

Room clean-up system: No

System integrity: 10E-7 Pa m3/s for entire system.

\section{Operating Conditions:}

Glovebox atmosphere: nitrogen/Ar

Glovebox pressure: -500 $\mathrm{Pa}$ differential to room

Gloves: $30 \mathrm{mil} / 15 \mathrm{mil}$ butyl rubber

Glovebox panel: Plexiglas (ck)

Glove ports: 16 per module (ck) 
Over-pressure protection: seal pots

Seal pot fluid: silicone fluid

Batch/Continuous: Batch

Catalyst temp $=500{ }^{\circ} \mathrm{C}$

Regen Z-Bed temp $=300^{\circ} \mathrm{C}$

Regen carrier gas: N2 @ $150 \mathrm{~m} 3 / \mathrm{h}$

Regen frequency: As-needed.

\section{Performance:}

Tritium: low $=1.26 \mathrm{~Bq} / \mathrm{m} 3 \rightarrow$ Purge

$$
\text { Medium }=6.7 \mathrm{GBq} / \mathrm{m} 3 \rightarrow \text { Purge }
$$

High $=>>$

Discharge $<8 \mathrm{MBq} / \mathrm{m} 3$ for discharge or $<\quad \mu \mathrm{Ci} / \mathrm{cc}$

Moisture: $\quad$ ppm (post Z-bed)

Oxygen: Low limit: 100 ppm

High Limit: 1000 ppm

Glovebox Background: (design goal) $0.1-1 \mu \mathrm{Ci} / \mathrm{cc}$

Purge rate: $0.51 / \mathrm{sec}$ or $30 \mathrm{l} / \mathrm{min}$

\section{Waste Streams:}

1. Job control waste (shoe covers, gaskets, paper)

2. Dump zeolite beds with HTO. (expect 5 liters/month)

3. Tritium contaminated nitrogen/argon to atmosphere.

\section{Comments:}




\section{Appendix B Vendor Information}

A number of vendors design and fabricate glovebox containment systems, including gas purification systems. Other vendors provide accessories such as moisture and oxygen analyzers, gloves, and glovebox panel glass. Vendors listed in the tables below were represented at the '97 American Glovebox Society Meeting in Lakewood, Colorado. Glovebox and gas purification system vendors are shown in Table B.1. Accessory vendors are shown in Table B.2.

Other instrument vendors such as Dwyer that makes Photohelic pressure gauges and MKS that makes pressure/flow controllers and Baratron pressure gauges may be found in the Thomas Register or through the World Wide Web. 
Table B.1 Confinement and Clean-up Systems Vendors

\begin{tabular}{|c|c|c|c|}
\hline Equipment/Service & Vendor & Address & Phone/fax/web-site \\
\hline Glovebox Systems & $\begin{array}{l}\text { Walker Stainless } \\
\text { Equipment Co., Inc. } \\
\text { (A Carlisle Company) }\end{array}$ & $\begin{array}{l}\text { New Lisbon, WI } 53950 \\
\text { Tavares, FL } 32778\end{array}$ & $\begin{array}{r}(800) 356-5734 \\
\operatorname{fax}(608) 562-3178 \\
\\
\operatorname{fax}(352) 343-2606 \\
343-7210\end{array}$ \\
\hline $\begin{array}{l}\text { Glovebox Systems, } \\
\text { Moisture Analyzers, } \\
\text { Glovebox Video } \\
\text { Microscope System }\end{array}$ & $\begin{array}{l}\text { Vacuum/Atmospheres } \\
\text { Company }\end{array}$ & $\begin{array}{l}4652 \text { West Rosecrans } \\
\text { Av. } \\
\text { P. O. Box } 1043 \\
\text { Hawthorne, CA } 90250\end{array}$ & $\begin{array}{r}(310) 644-0255 \\
\text { fax }(310) 970-0980 \\
\text { www.vac-atm.com }\end{array}$ \\
\hline $\begin{array}{c}\text { Glovebox Design and } \\
\text { Fabrication, } \\
\text { Control systems }\end{array}$ & $\begin{array}{l}\text { Diversified Metal } \\
\text { Products, Inc. }\end{array}$ & $\mid \begin{array}{l}\text { P. O. Box } 1404 \\
3710 \text { North Yellowstone } \\
\text { Idaho Falls, ID } 83401\end{array}$ & $\begin{array}{r}(208) 529-9655 \\
\operatorname{fax}(208) 529 .-9836\end{array}$ \\
\hline $\begin{array}{c}\text { Shielded Hot Cells and } \\
\text { Gloveboxes, } \\
\text { Decon Services }\end{array}$ & $\begin{array}{l}\text { Hot Cell Services } \\
\text { Corporation }\end{array}$ & $\begin{array}{l}2262685^{\text {th }} \text { Place South } \\
\text { Kent, WA } 98031\end{array}$ & $\begin{array}{r}(206) 854-4945 \\
\operatorname{fax}(206) 854-4947 \\
\text { www.hotcell.com }\end{array}$ \\
\hline $\begin{array}{c}\text { Glovebox Systems and } \\
\text { Accessories }\end{array}$ & Labconco Corporation & $\begin{array}{l}8811 \text { Prospect Avenue } \\
\text { Kansas City, MO } 64132\end{array}$ & $\begin{array}{r}(800) 821-5525 \\
(816) 333-8811 \\
\operatorname{fax}(816) 363-0130\end{array}$ \\
\hline $\begin{array}{l}\text { Process Enclosures and } \\
\text { Equipment Systems }\end{array}$ & Merrick \& Company & $\begin{array}{l}\text { P. O. Box } 22026 \\
10855 \text { East Bethany Dr. } \\
\text { Denver, CO } 80222\end{array}$ & $\begin{array}{r}(800) 544-1714 \\
(303) 751-0741 \\
\operatorname{fax}(303) 751-2581\end{array}$ \\
\hline $\begin{array}{c}\text { Custom Isolation } \\
\text { Barrier Systems and } \\
\text { Gas Purification } \\
\text { Systems }\end{array}$ & M. Braun Inc. & $\begin{array}{l}\text { U. S. Office } \\
65 \text { Parker St., Unit } 5 \\
\text { Newburyport, MA } \\
01950\end{array}$ & $\begin{array}{r}(800) 531-6217 \\
(508) 462-1770 \\
\operatorname{fax}(508) 462-1862\end{array}$ \\
\hline Glovebox Design & $\begin{array}{l}\text { Experienced Solutions } \\
\text { Consultants (ESC) }\end{array}$ & $\begin{array}{l}16821 \mathrm{~W} .74^{\text {th }} \mathrm{Av} \\
\text { Arvada, CO } 80007\end{array}$ & $\begin{array}{r}(303) 423-0054 \\
\operatorname{fax}(303) 456-0389\end{array}$ \\
\hline
\end{tabular}

